\title{
Marine Archaeological Survey for the Webster to Seadrift Pipeline Project in Calhoun and Jackson Counties, Texas
}

John Rawls

Michael C. Tuttle

Jim Hughey

Michael Quennoz

Follow this and additional works at: https://scholarworks.sfasu.edu/ita

Part of the American Material Culture Commons, Archaeological Anthropology Commons, Environmental Studies Commons, Other American Studies Commons, Other Arts and Humanities Commons, Other History of Art, Architecture, and Archaeology Commons, and the United States History Commons

Tell us how this article helped you.

This Article is brought to you for free and open access by the Center for Regional Heritage Research at SFA ScholarWorks. It has been accepted for inclusion in Index of Texas Archaeology: Open Access Gray Literature from the Lone Star State by an authorized editor of SFA ScholarWorks. For more information, please contact cdsscholarworks@sfasu.edu. 


\section{Marine Archaeological Survey for the Webster to Seadrift Pipeline Project in Calhoun and Jackson Counties, Texas}

\section{Creative Commons License}

\section{(c) (1) \&}

This work is licensed under a Creative Commons Attribution-NonCommercial 4.0 International License 


\section{GRAY \& PAPE HERITAGE MANAGEMENT}

\section{Marine Archaeological}

Survey for the Webster to Seadrift Pipeline Project in Calhoun and Jackson Counties, Texas

LEAD FEDERAL AGENCY: United States Army Corps of Engineers Galveston District

Texas Antiquities Permit No. 9004

\section{PREPARED FDR: BIO-WEST, Inc. 1018 Frost Street Rosenberg, Texas 77471}

PREPARED BY: Gray \& Pape, Inc. 110 Avondale Street Houston, Texas 77006 


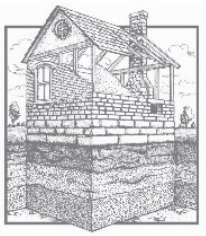

\section{GRAY $\&$ PAPE \\ HERITAGE MANAGEMENT}

Project No. 19-72324.001

Marine Archaeological Survey for the Webster to Seadrift Pipeline Project in Calhoun and Jackson Counties, Texas

Texas Antiquities Permit No. 9004

Lead Agency:

The United States Army Corps of Engineers, Galveston District

Prepared for:

BIO-WEST, Inc.

1018 Frost Street

Rosenberg, Texas 77471

Prepared by:

John Rawls, M.A., RPA

Michael C. Tuttle, Ph.D., RPA

Jim Hughey, M.A., RPA

Michael Quennoz

Gray \& Pape, Inc.

110 Avondale Street

Houston, Texas 77006

(713) 541-0473

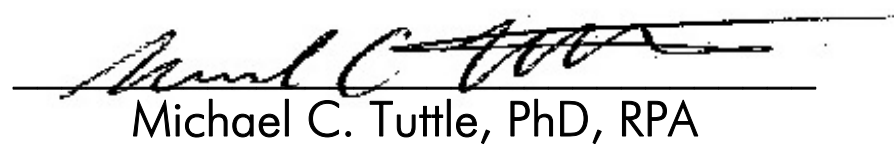

Principal Investigator

May 29, 2020 


\section{ABSTRACT}

Under contract to BIO-WEST, Inc., Gray \& Pape, Inc., of Houston, Texas, conducted a Phase I marine archaeological survey for the proposed Webster to Seadrift Pipeline Project in Calhoun and Jackson counties, Texas. Enterprise Products Operating LLC sponsored the archaeological survey. All marine fieldwork and reporting activities were completed with reference to state law (Antiquities Code of Texas [Title 9, Chapter 191 of the Texas Natural Resources Code] and Texas State rules found in the Texas Administrative Code [Title 13, part 2, Chapters 26 and 28]) for cultural resources investigations. Work was completed under Texas Antiquities Permit Number 9004. The United States Army Corps of Engineers, Galveston District has been identified as the lead federal agency. All project records are curated at the Center for Archaeological Studies at Texas State University in San Marcos, Texas.

The Phase I underwater archaeological investigation assessed the number, locations, cultural affiliations, components, spatial distribution, data potential, and other salient characteristics of potential submerged cultural resources within the proposed project area. The linear project area includes approximately 391 hectares (967 acres) of submerged land in Calhoun and Jackson counties, Texas. The investigation included a comprehensive magnetic and acoustic remote sensing survey and target analysis designed to determine the presence or absence of potentially significant remote sensing targets that might be affected by proposed project activity.

Background research revealed that there are no previously recorded sites within the Area of Potential Effects and that there have been two previous cultural resource surveys (Pearson et al. 1993; Gearhart 2016), conducted between 1993 and 2016, partially within the project Area of Potential Effects. Research also revealed that the 50-meter (164-foot) avoidance areas, as mandated by Texas Administrative Code, Title 13, Part 2, Chapter 26, for three previously recorded magnetic anomalies (Mag 7-Mag 9) identified by Gearhart (2016) are partially located within the survey area. These three magnetic anomalies were recommended for avoidance as they represent potential cultural resources.

The grid for the remote sensing survey within the open waters of Lavaca Bay consisted of a total of 19 track lines (Lines 1-16, 18,19,37, and 38) at 20-meter (65.6-foot) line spacing oriented parallel to an existing pipeline right-of-way. The remaining portions of the project area within Lavaca River and Catfish Bayou were surveyed at 20-meter (65.6-foot) line spacing (Lines 0, 17, 22-35, and 39-43) oriented perpendicular to the survey corridor. The marine field investigations consisted of a magnetometer and side-scanning sonar investigation of the proposed project area in safely navigable waters between July 29 and 30, 2019, and required approximately 60-person hours to complete.

A total of 284.6 kilometers (176.9 linear survey miles) were transected utilizing the magnetometer and side-scan sonar. Comprehensive analysis of the magnetic and acoustic data recorded for this project resulted in the identification of 127 discrete magnetic anomalies, with 80 meeting or exceeding the Pearson and Linden (2014) 50-gamma/65-foot criteria. A total of 43 of the 80 anomalies that meet or exceed the 50-gamma/65-foot criteria are associated with existing pipelines. While the remaining 37 anomalies, consisting of 22 magnetic targets, meet and/or exceed the 50-gamma/65-foot criteria, they do not meet Gearhart's 2011 magnetic orientation and spatial criteria to be considered potentially significant. They are interpreted as relic oils wells, ferrous debris scatters associated with the oil and natural gas industries and recreational and commercial fishing activities, and miscellaneous debris from previous tropical storms and hurricanes. Review of the sonar record revealed two distinct acoustic targets (SST-1 and SST-2) consisting of the remnants of a subsequent exploratory oil well and a subsided pipeline trench. Based on the applied criteria, these magnetic and acoustic targets do not exhibit any 
characteristics associated with historic shipwrecks and/or other significant submerged cultural resources. As such, the recommended management action for magnetic targets, Numbers 1-22, as well as acoustic targets, SST-1 and SST-2, is no further archaeological investigations.

One magnetic target, Number 23, situated outside of the Area of Potential Effects, is associated with previously recorded anomaly Mag 8, which was deemed as potential historic shipwreck remains. While it is located outside of the Area of Potential Effects, it was recorded within the 50-meter (164 foot) avoidance buffer of previously recorded anomaly Mag 8. No magnetic signatures were recorded within the portion of the avoidance buffer that is within the Area of Potential Effects. The lack of any residual magnetic signatures of the anomaly within the Area of Potential Effects indicate that no portions of the ferrous source objects for Mag 8 extend into the current survey area or the construction footprint; and therefore, the submerged target or its avoidance buffer will not be impacted by the proposed activities.

Additionally, no magnetic signatures associated with previously recorded anomalies Mag 7 and Mag 9 were identified in the 50-meter (164-foot) avoidance buffers within the Area of Potential Effects. The lack of any residual magnetic signatures of anomalies (Mag 7 and Mag 9) within the Area of Potential Effects indicate that no portions of the ferrous source objects for these two magnetic anomalies extend into the current survey area or the construction footprint; and therefore, the submerged targets or their avoidance buffers will not impacted by the proposed activities.

The recommended management action for the portions of the 50-meter (164-foot) avoidance buffers for Mag 7, Mag 8, and Mag 9 that extend partially into the current survey area is avoidance from any bottom disturbing activities. If bottom disturbing activities within the buffer buffers cannot be avoided, additional marine archaeological investigations in the form of diver-ground-truthing will be required to determine the nature and historical significance of the source magnetic objects. 


\section{TABLE OF CONTENTS}

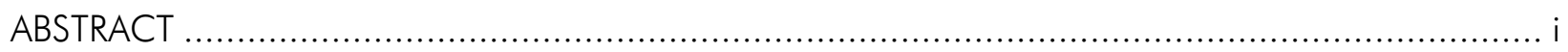

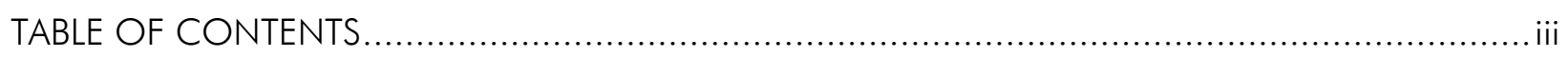

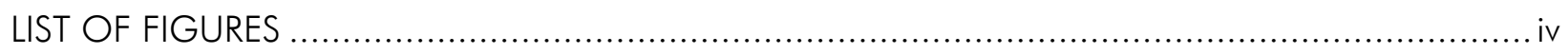

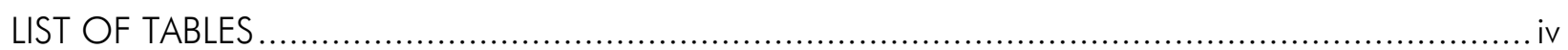

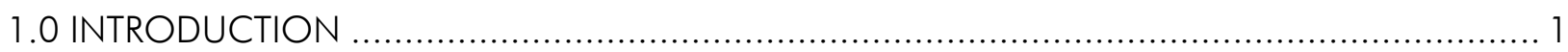

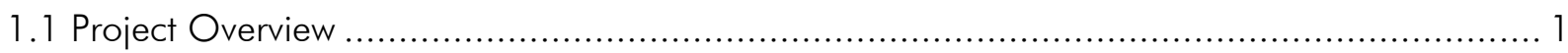

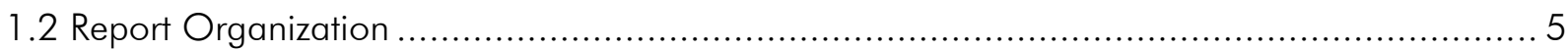

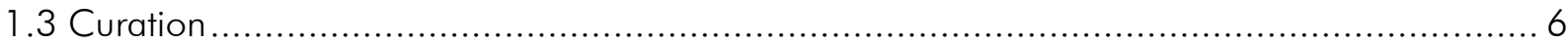

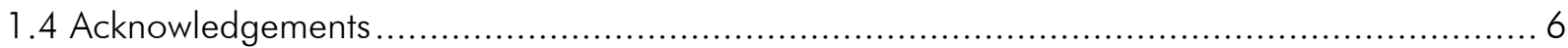

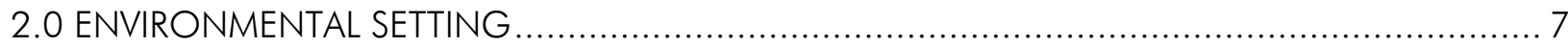

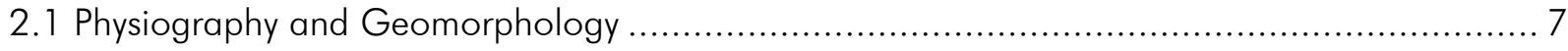

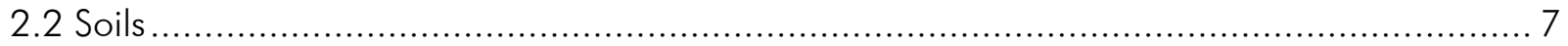

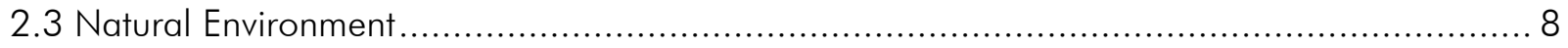

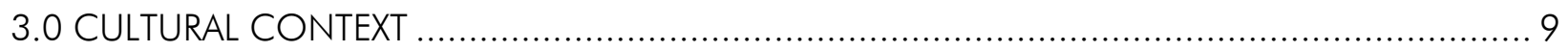

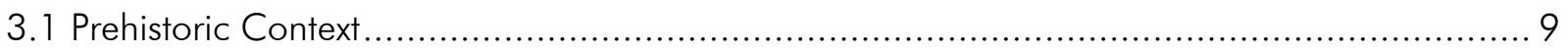

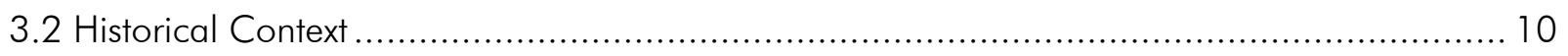

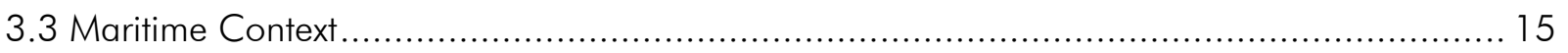

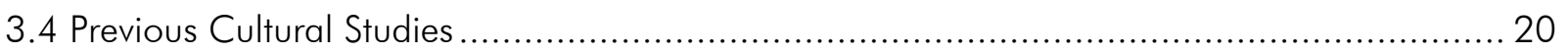

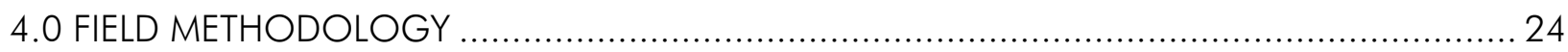

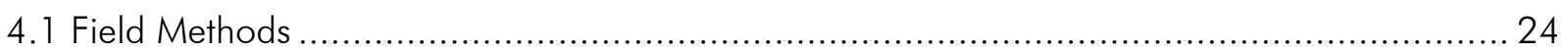

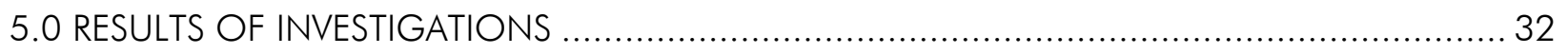

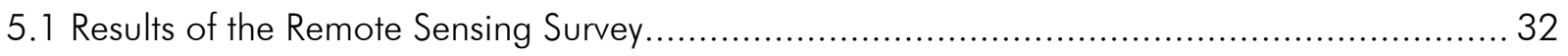

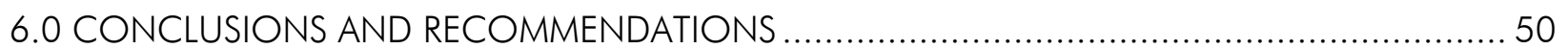

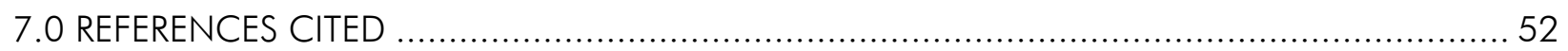

APPENDIX: PROJECT PLANS 


\section{LIST OF FIGURES}

Figure 1-1. Project area location in Calhoun and Jackson counties, Texas................................. 2

Figure 1-2. Project workspaces as currently planned overlaid on aerial imagery. ......................... 3

Figure 1-3. Project workspaces as currently planned overlaid on aerial imagery. ........................ 4

Figure 3-1. NOAA AWOIS, ENC, and THC reported shipwrecks and previously recorded surveys and sites within and just outside a 1.6-kilometers $(1$-mile) study radius of the project area.................. 21

Figure 4-1. BIO-WEST's project survey vessel. View is to the south. ........................................ 24

Figure 4-2. Planned and actual survey track lines for the Webster to Seadrift Pipeline project area,

Calhoun and Jackson counties, Texas.................................................................................. 26

Figure 5-1. Magnetic contour map of the project area. Note the constant anomaly along the existing

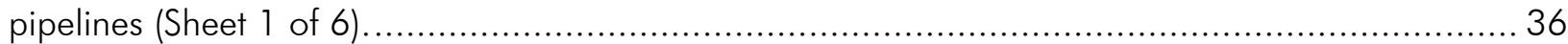

Figure 5-2. Magnetic contour map of the project area. Note the constant anomaly along the existing

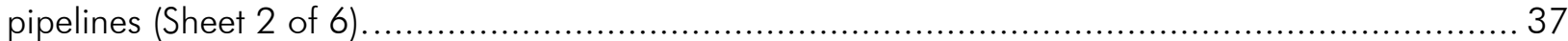

Figure 5-3. Magnetic contour map of the project area. Note the constant anomaly along the existing

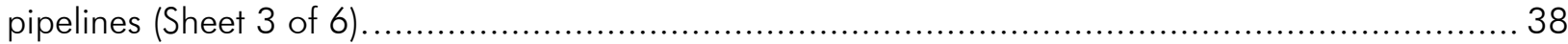

Figure 5-4. Magnetic contour map of the project area. Note the constant anomaly along the existing

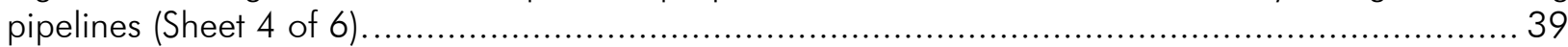

Figure 5-5. Magnetic contour map of the project area. Note the constant anomaly along the existing

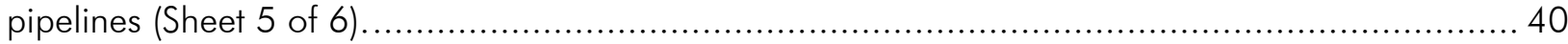

Figure 5-6. Magnetic contour map of the project area. Note the constant anomaly along the existing

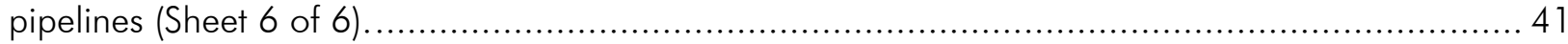

Figure 5-7. Side-scan sonar mosaic of the project area (Sheet 1 of 6) ................................ 44

Figure 5-8. Side-scan sonar mosaic of the project area (Sheet 2 of 6) . ................................. 45

Figure 5-9. Side-scan sonar mosaic of the project area (Sheet 3 of 6 ) . ............................... 46

Figure 5-10. Side-scan sonar mosaic of the project area (Sheet 4 of 6). ................................ 47

Figure 5-11. Side-scan sonar mosaic of the project area (Sheet 5 of 6 ). ................................ 48

Figure 5-12. Side-scan sonar mosaic of the project area (Sheet 6 of 6 ). .................................. 49

\section{LIST OF TABLES}

Table 3-1. Wrecks Reported within Lavaca Bay............................................................. 20

Table 5-1. Recorded Magnetic Anomalies......................................................................... 33

Table 5-2. Magnetic Targets and Associated Anomalies that Meet the 50-Gamma/65-Foot Criteria. 


\subsection{INTRODUCTION}

Gray \& Pape, Inc. (Gray \& Pape), of Houston, Texas, conducted a Phase I marine cultural resources survey in support of the planned Webster to Seadrift Pipeline Project. The archaeological survey was sponsored by Enterprise Products Operating LLC under subcontract to BIO-WEST, Inc (BIO-WEST). The total Area of Potential Effects (APE) for the project is a 305-meter (1,000-foot) wide corridor, approximately 6.9 kilometers (10.5 miles) in length consisting of approximately 391 hectares (967 acres) of submerged land.

The submerged land for the APE is in State Tract numbers 79, 80, 94, and 95, which are administered by the Texas General Land Office (TxGLO), an agency of the State of Texas created to manage the public domain. As such, the Antiquities Code of Texas (Texas Natural Resource Code, Title 9, Chapter 191) applies. Marine fieldwork and reporting activities were completed with reference to state standards (Antiquities Code of Texas [Title 9, Chapter 191 of the Texas Natural Resources Code] and Texas State Guidelines found in the Texas Administrative Code [Title 13, Part 2, Chapters 26 and 28]) for cultural resources investigations. Work was completed under Texas Antiquities Permit Number 9004 issued by the Texas Historical Commission (THC) on July 30, 2019. As the project is within the navigable waters of the United States, the United States Army Corps of Engineers (USACE), Galveston District has been identified as the lead federal agency. Therefore, the project is considered a federal undertaking and must comply with Section 106 of the National Historic Preservation Act (NHPA) of 1966, as amended, the regulations of the Advisory Council of Historic Preservation (30 CFR Part 800), and the National Environmental Policy Act of 1969, as amended.

\subsection{Project Overview}

The project is located on the Kamey and Point Comfort, TX United States Geological Survey (USGS) 7.5-minute topographic quadrangle maps extending northeast across Lavaca Bay in Calhoun County and the Lavaca River and Catfish Bayou in Jackson County, Texas (Figure 1-1) (USGS 1995a, 1995b) and the National Oceanic and Atmospheric Administration (NOAA) Chart 11317, entitled Matagorda Bay: Including Lavaca and Tres Palacios Bays (2014). The charted depths near the project area range between 0.6 to 1.5 meters (2.0 to 5.0 feet). Actual water depths recorded at the time of survey ranged from 0.3 to 1.5 meters ( 1.0 to 5.0 feet).

The project is expected to take place within a 305-meter (1,000-foot) wide corridor, approximately 6.9 kilometers (10.5 miles) in length at its greatest extent. For this project, the APE is defined as the total length and width of the proposed pipeline corridor. At the requests of the THC, the actual area surveyed extended beyond the APE in order to acquire data immediately outside and adjacent to the APE.

To complete the Lavaca Bay and Lavaca River crossings, the proposed pipeline installation will utilize a horizontal directional drill (HDD) within three separate HDD sections (HDD1-HDD3; See Appendix; Figures 1-2 and 1-3). To begin, the HDD contractor will mobilize all marine equipment necessary to complete the HDDs including two spud barges measuring 45.7248.76 meters (150-160 feet) long and 12.19 meters (40 feet) wide and two deck barges measuring 27.43 (90 feet) long and 9.14 meters (30 feet) wide. One spud barge and one deck barge will be mobilized to HDD 1, and one spud barge and one deck barge will be mobilized to HDD 3. A drilling rig will be set up on each of the spud barges, and each of the deck barges will be set-up directly behind each 


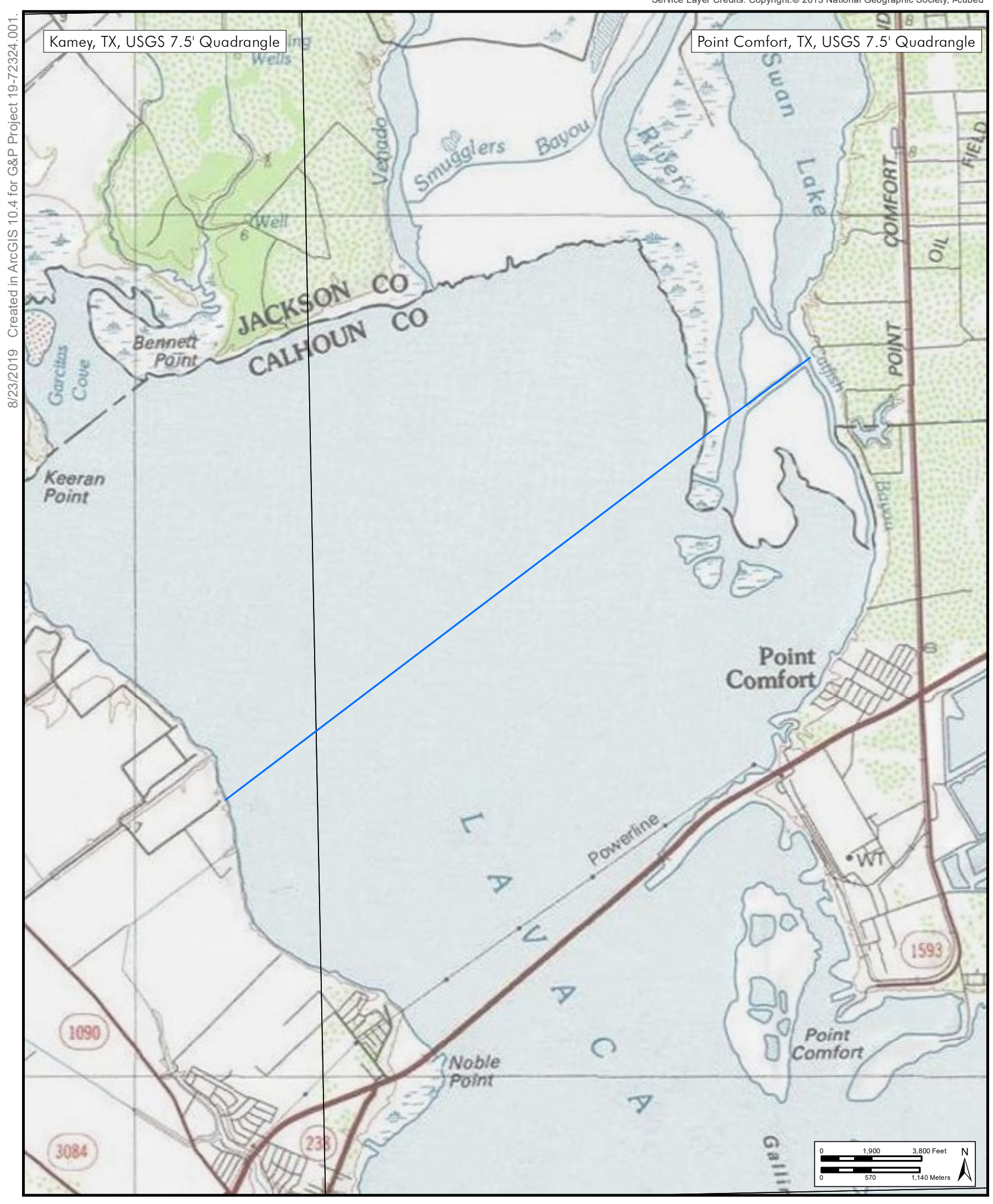

Figure 1-1

Project area location in Calhoun and Jackson Counties, Texas. 
REMOVED FROM PUBLIC COPY

Project workspaces as currently planned overlaid on aerial imagery. 
REMOVED FROM PUBLIC COPY

Project workspaces as currently planned overlaid on aerial imagery. 
of the entry/exit point in the workspaces noted (see Appendix; Figures 1-2 and 1-3). The deck barge will then be placed parallel to the spud barge, and both will be anchored to the ground and to each other. Turbidity curtains will then be installed and anchored around the HDD entry/exit points and barge setup area as needed. Simultaneously, land-based drilling rigs will be set up at the HDD entry points onshore, as noted in the drawings. Upon completion of the barge rig and land rig setups, pilot-hole drilling operations will commence. The HDD contractor will use two 30.5centimeter (12-inch) diameter pilot bits to drill toward each other using the profile established in the project drawings (see Appendix), and a gyroscopic steering tool will monitor the pilothole and provide guidance. Once the pilot bits meet, the land-based rig will back out of the hole while the water-based rig tool will follow it all the way to the HDD 1/3 Entry point onshore. The 30.5-centimter (12-inch) pilot will eliminate the need to perform a reaming step, and upon completion of the pilot drilling phase, the 8 -inch diameter pipe will be pulled back into the pilot hole. The pipe will be pulled back to just past the water HDD entry/exit and attached to a pile/pier that is installed to hold the pipe until HDD 2 is complete and tie-in operations are ready to commence.

Upon completion of HDDs 1 and 3, the spud barges and deck barges will be turned around and moved slightly to the proposed HDD 2 entry and exit points and then re-anchored to the bottom of the bay and to each other. Drilling operations for HDD 2 will then commence in a similar fashion, except using two water-based spud barges/rigs to drill the pilot hole. The pilot drills will meet in the middle, and the spud barge/rig set up at the proposed HDD 2 exit point (western most side of HDD 2) will pull the pilot bit back to the exit point, and the pilot from the entry side will follow. Once pilot drilling operations are complete, the drill string will be floated out into the bay and moved toward the HDD 2 exit point. $\mathrm{H}$-braces will be installed in the bay at locations where oysters have been confirmed absent to keep the pipe string in position and off of the bottom of the bay, eliminating any possibility of oyster bed impact. The drilling rig located on the spud barge at the proposed HDD 2 entry point will pull the floated pipe into the pilot hole, while the spud barge located at the HDD 2 exit point will use a crane to elevate the pipe and assist with pulling the pipe into the pilot hole.

Pulling operations will leave a tail on the pipe string pulled into the pilot hole that is long enough to reach to the pipe left at the HDD 3 entry point. The spud barge will be moved slightly to elevate the pipe and make an above water tie-in weld between HDD 3 and HDD 2. Once the tie-in weld is complete, the 91.44meter (300-foot) section of pipe between the pipe will be pulled and lowered into a trench excavated from a long reach backhoe operated from the barge. Once this section of the line is fully lowered into the trench, it will be backfilled. Turbidity curtains will remain as needed to allow for further settlement of the silt suspended during the trenching and backfill operations.

The tie-in between HDD 1 and HDD 2 will begin upon completion of the HDD 2/3 tie-in. Beginning from the barge used to pull in pipe at HDD 2, the pipe will be disconnected from the pull-back rig and suspended from the barge. Tie-in welds will be made to connect the pipe between the HDD 1 and 2 entry points. Once complete, the 91.44-meter (300-foot) section of pipe between the HDD 2 and 3 entry points will be slowly lowered into a trench excavated from a long-reach excavator operated from the barge to a depth of 1.52 meters (5 feet) below the bottom of the bay. Upon completing all lowering-in, the trench will be backfilled, and final clean-up and demobilization will begin. Turbidity curtains will be maintained as long as needed.

\subsection{Report Organization}

This report is organized into seven numbered chapters and one appendix. Chapter 1.0 provides an overview of the project. Chapter 2.0 presents an overview of the environmental 
setting and geomorphology of the project area. Chapter 3.0 presents a discussion of the cultural context associated with the project area as well as previous surveys and cultural resources in the area. Chapter 4.0 presents the methodology developed for these investigations. The results of the survey are presented in Chapter 5.0. Chapter 6.0 presents the investigation summary and provides recommendations based on the results of field survey. A list of all references cited is provided in Chapter 7.0. Project plans are provided as an appendix.

\subsection{Curation}

No diagnostic or non-diagnostic artifacts were collected in the course of the current survey. As a project permitted through the THC, however, Gray \& Pape submitted project records to the Center for Archaeological Studies (CAS) at Texas State University in San Marcos, Texas.

\subsection{Acknowledgements}

The successful completion of this project was made possible by a joint effort between $\mathrm{BIO}$ WEST and Gray \& Pape personnel. BIO-WEST provided all equipment and watercraft necessary for the survey. Research on various aspects of this project was conducted by Project Manager Jim Hughey, M.A., RPA, Principal Investigator Michael Tuttle, Ph.D., RPA, and Marine Archaeologist Michael Quennoz. Background research included consultation of online research archives maintained by the THC, resources maintained by the Soil Service Staff of the Natural Resources Conservation Service of the United States Agriculture Department (SSS NRCS USDA), and numerous marine targets datasets.

The marine survey was conducted on July 29 and 30, 2019. The survey team included BIOWEST's Doug Williamson and Antonio Neves and Gray \& Pape's Jim Hughey, working under the supervision of Michael Tuttle. Magnetic and acoustic data analysis was conducted by Marine Archaeologist John Rawls, M.A., RPA, and reviewed by Michael Tuttle. John Rawls, Michael Tuttle, Michael Quennoz, and Jim Hughey prepared the report. Graphics were produced by Duncan Hughey and Tony Scott, M.A. Jessica Bludau edited and produced the report. 


\subsection{ENVIRONMENTAL SETTING}

\subsection{Physiography and Geomorphology}

The APE is primarily in the upper portion of Lavaca Bay and extends across the Lavaca River and Catfish Bayou. Lavaca Bay is a broad, flat, and shallow northern extension of Matagorda Bay, measuring 8 kilometers (5 miles) wide and 23 kilometers (14 miles) long at its greatest extents. It is separated from the Gulf of Mexico by Matagorda Island, a post glacial barrier island of dunes and wash over fans. The seafloor in the present-day APE consists mostly of estuarine mud, having no discernable slope, except for isolated areas of shell reef. Review of the United States Coast and Geodetic Survey (USCGS) 1888 Pass Cavallo, Lavaca, and San Antonio Bays navigation chart shows historic water depth in the APE was charted as about 1.7 meters (5.5 feet), Mean Low Water (USCGS 1888). The National Oceanic and Atmospheric Administration (NOAA) charts the depth as closer to 1.5 meters (5 feet), Mean Lower Low Water, consistent with depths observed.

The present coastline of the Texas Gulf Coast has fluctuated relatively little in the past approximately 3,000 years. However, prior to 8,000 B.C., the Gulf Coast extended to the southeast. Towards the end of the Pleistocene era, 20,000 years ago, global temperatures rose, and sea levels rapidly began to rise. By 8,000 B.C., shorelines worldwide had progressed inland, with the flooding of the valleys of major streams along the Texas Coast, such as the Trinity, Lavaca, Guadalupe, Aransas, and Nueces Rivers (Ricklis and Weinstein 2005). As a result, the earliest forms of the modern coastal bays found in Texas were created.

Around 9,500 years ago in Lavaca Bay, the Lavaca River and Garcitas Creek drainage basins became a single tidal estuary inundating the location to the APE. Gearthart (2017:3) describes approximately 27 meters (90 feet) of fluvial sediments have been deposited over the location of the APE. These buried paleo landscapes are archaeologically important because they were very likely exposed landforms (i.e. relic levees) within the floodplains during the early periods of human habitation in North America. The source of freshwater along with the ecological diversity of an estuarine environment would create ideal conditions for prehistoric occupations.

\subsection{Soils}

The terrestrial environmental setting found nearest to the western terminus of the project corridor consists of the Lake Charles-Dacosta soil association, a nearly level to sloping, noncalcareous, somewhat poorly drained clayey soils of the uplands (Mowery and Bower 1978:2).

More specifically, there are two soil types mapped in this vicinity. Laewest clay, 0 to 1 percent slopes (La) and Francitas clay loam, 0 to 1 percent slopes, rarely flooded ( $\mathrm{Fr}$ ). Laewest clay, 0 to 1 percent slopes (La) is described as "very deep, moderately well-drained level to gently level soils that formed in clayey flood basin deposits on alluvial plains or deltas of the Beaumont Formation and are situated on broad flat coastal plains" (USDA 2019). Francitas clay loam, 0 to 1 percent slopes, rarely flooded (Fr) is descried as "nearly level soils within 8 kilometers ( 5 miles) of intercoastal bays and is less than 4.5 meters (15 feet) above sea level" (Mowery and Bower 1978:13).

The terrestrial environmental setting found nearest to the eastern terminus of the project corridor consists of Swan-Placedo-Aransas soil associations, a very poorly drained and poorly drained, saline, slowly permeable and very slowly permeable, loamy, and clayey soils (Miller 1997:12). The mapped soil types in this vicinity are Swan clay, 0 to 1 percent slopes, 
frequently flooded, occasionally ponded (Sw), which is described as very deep, slowly permeable, very poorly drained clayey soils on bottom land that formed in saline, calcareous, loamy, and clayey alluvium (Miller 1997:8586), and Placedo clay, 0 to 1 percent slopes, frequently flooded, occasionally ponded (Pd), described as very deep, very permeable, very poorly drained clayey soils on flood plains that formed in saline, calcareous, and clayey alluvium (Miller 1997: 84).

\subsection{Natural Environment}

Lavaca Bay is fed sediment-laden freshwater from the north via the Lavaca River to the northeast, Venado Creek to the north, and Garcitas Creek to the northwest. In Lavaca Bay, clayey or silty sand along the bay margins give way to predominantly silty clays across most of the bay bottom (Folger 1972).

Lavaca Bay is defined as an open-bay bottom system that is influenced by ocean waters via a tidal inlet, with marshes and intertidal flats on the periphery of the estuary, and with confluence of riverine systems in the estuary. They are the subtidal portions of the estuary situated below the extreme low spring tide. Bottom types consist typically of sand or mud with coarser sediments near the delta areas associated high energy inflows, clayey sediments near the river (i.e. Lavaca River and Garcitas (reek) inflows, and muddy bottoms in the open-bay system (Armstrong 1987:1).

\subsubsection{Climate}

The climate of the area is predominately maritime, heavily influenced by the warm and very moist air masses from the Gulf of Mexico, producing a humid subtropical climate (Mowery and Bower 1978: 57). Winds usually trend from the southeast or south-southeast, except during winter months when high-pressure systems can bring in polar air from the north. Summers are warm and winters tend to be mild. The mean daily maximum temperature for the year is $26.5^{\circ}$ Celsius (79. $7^{\circ}$ Fahrenheit), and the mean daily minimum temperature is $16.2^{\circ}$ Celsius (61. $1^{\circ}$ Fahrenheit). Precipitation comes in both thunderstorms and trace amounts. Hurricanes are known in the region, producing high winds and copious amounts of rain. Average annual rainfall is 65.8 centimeters (25.9 inches) (Mowery and Bower 1978; Miller 1997).

\subsubsection{Tide}

During the field activities for this project, the tide at the Port Lavaca, TX Station, the closest tide monitoring station, was reported to range from a low of 0.18 meters ( 0.6 feet) at $1: 28$ am to a high of 0.27 meters ( 0.9 feet) at $12: 53 \mathrm{pm}$ for a total range of 0.45 meters (1.4 feet) on Monday July 29, 2019, and from a low of 0.21 meters (0.7 feet) at $1: 28$ am to a high of 0.27 meters ( 0.9 feet) at $12: 53 \mathrm{pm}$ for a total range of 0.48 meters ( 1.5 feet) on Tuesday July 30, 2019. 


\subsection{CULTURAL CONTEXT}

\subsection{Prehistoric Context}

\subsubsection{Paleoindian Period}

Evidence is sparse for Paleoindian habitation, and much of what is known about the period in the current project area comes from a compilation of materials gathered from around the state of Texas and North America. At the close of the Pleistocene, large game hunters crossed the Bearing Strait, and within a few millennia had penetrated into South America (Newcomb 1961). The Paleoindian people traveled in small bands and were megafauna hunter-gatherers with the bulk of their meat protein derived from mammoths, mastodons, giant bison, and giant sloths. It is believed that in south Texas, the Paleoindian people traveled in small groups of non-specialized hunters and gatherers rather than the larger groups normally associated with the big game hunters of the Great Plains (Hester 1976). These groups carried with them an easily recognizable stone tool material culture, though little is known about their wooden or bone tools or their clothing types. Diagnostic spear points such as fluted Clovis, Folsom, and Plainview points can be used to identify a site's Paleoindian component, and the nature of these points demonstrate the population's hunting style. Paleoindian-era points are large and designed to be attached to a spear. No evidence of bow and arrow hunting has been found associated with this period (Newcomb 1961).

\subsubsection{Archaic Period}

After the Pleistocene, the Gulf of Mexico's encroachment onto the Texas coast created estuaries along the shoreline. The formation of these estuaries provided the Archaic people of the Texas coast with a ready supply of marine food resources (Jurgens 1989). This shift in food supply is seen as the pivotal transition point between the Paleoindian and Archaic periods in the region (Aten 1984; Newcomb 1961).
Within the boundaries of the south Texas coast, the Aransas complex has been identified based on a suite of tools indicative of a lifestyle based on marine resources (Campbell 1958; Corbin 1974). Material culture recovered from Archaic sites within the south Texas region includes shell artifacts such as conch columella gouges, adzes, and awls. Stone projectile points recovered from Archaic sites in the region include Abasolo, Palmillas, Ensor, Refugio, and Tortugas types (Turner and Hester 1993).

\subsubsection{Late Prehistoric}

The Prehistoric period continues from the end of the Archaic period to the Historic period ushered in by the Spanish missions and AngloAmerican settlers. During the Late Prehistoric stage in south Texas, two cultural complexes appear to have existed. The first complex was located further east on the coast and appears to have been affiliated with the Goose Creek complex (Jurgens 1989). The second complex has been called the Rockport complex (Jurgens 1989). During this period, there is a shift to the almost exclusive use of arrow points such as Perdiz and Scallorn (Turner and Hester 1993), and almost every group had pottery. It is during this period that two similar cultural groups, known today as the Coahuiltecans and the Karankawas, are identifiable both ethnographically and archaeologically.

Within south Texas, these two dominant cultural groups extended south of Galveston Bay to the Rio Grande and as far west as present-day San Antonio. The coastal group was known as the Karankawas and the inland group was known as the Coahuiltecans. Most of what is known of both groups comes from the time that Cabeza de Vaca spent with them as a captive and trader (Newcomb 1961).

The Coahuiltecans dominated the majority of the land of present-day Aransas County. Their language group, which is related to the Hokan 
group of languages of California, extended from the Gulf Coast far west to present day San Antonio (Aten 1984). The Coahuiltecans were subdivided into over two hundred small bands with four or five groups living within the south Texas region. The Aranamas dwell primarily between the San Antonio and Guadalupe Rivers. South of the Aranamas was a group known as the Orejons, who lived along the lower Nueces River. The Pachal group lived near the junction of the Frio and Nueces Rivers and possibly even crossed the Rio Grande.

The Karankawas, whose language was also in the Hokan group (Aten 1984), extended from Galveston Bay southwestwards as far as the present site of Corpus Christi Bay. As described by Newcomb (1961), seven proper names are associated with the culture. Researchers subdivide these names into five distinct groups based on geography. The Capoques and the Hans lived in the area between Galveston Bay and the Brazos River. The Kohanis lived south of the Capoques and the Hans at the mouth of the Colorado River. The Karankawa proper (which included the Korenkake, Clamcoets, and Carancaguacas) lived in the region of Matagorda Bay. Along Copano Bay and St. Joseph Island, were the Kopanos (Newcomb 1961).

\subsection{Historical Context}

\subsubsection{Historic Period}

With the discovery of the New World by Columbus in 1492, the Spanish conducted numerous other voyages of exploration along the American continents during the early sixteenth century. J.H. Parry (1966) indicates that the Spanish had three general stages of growth in the New World: the island stage, the Mexican stage, and the Isthmian or Peruvian stage. After the Caribbean Islands were exploited of their easy wealth, Cortes' conquest of Mexico 1519-1521 encouraged the settlement and exploration of the continent proper. From 1522, the average size and number of ships sailing from Spain to the
Americas steadily increased (Parry 1966). It was during this period when the Texas coast was initially examined, and at a high cost.

The earliest Spanish examinations along the west Gulf Coast was that of Alonso Alvarez de Pineda, which was initiated in 1518. From Florida to Mexico, via the Mississippi and the coast of modern-day Texas, new discoveries were made. Unfortunately, the natives of the region were hostile and many of the explorers were killed and all but one ship lost; however, the Gulf of Mexico was successfully mapped (Morison 1974; Johnson 2002). The next voyage to the region was that of Panfilo Narvaez in 1527-1528. Like that of Pineda this exploration ended in tragedy, which was slightly self-imposed. Narvaez sailed to Florida with five vessels and several hundred soldiers, sailors, and colonists. Dismissing his vessels, he and 260 of his men landed and attempted to venture around parts of the Gulf and meet the ships at a prearranged point. All did not go as planned, the natives were hostile, the ships never reestablished contact, and somewhere near the Mississippi River new vessels were constructed in an attempt to return to Mexico. Only four adventurers survived the expedition to make their way to safety. One of the survivors was named Alvar Nunez Cabeza de Vaca, who left an account of this 8-year misadventure on the Texas coast and interior (Morison 1974; Johnson 2002).

Another failed Spanish mission that may have encountered Matagorda Bay was that of the famed Hernando de Soto. Like Narvaez, de Soto landed in Florida and during 1539 began his adventures to the north and west. After encountering the Mississippi River in 1541 and exploring further west along the larger tributaries, De Soto died in 1542. Luis de Moscoso Alvarado took command, built several vessels during the spring of 1543, sailed down the Mississippi to the Gulf of Mexico, and followed the coast to the Panuco River, in Spanish held territory. It is conjectured that they may have entered Matagorda and Corpus Christi Bays along the coast of Texas for water 
and provisions, however, little was made of the discoveries (Morison 1974; Johnson 2002).

With the confines of the Gulf of Mexico known and mapped by the mid sixteenth century, the region was not the focus of intensive exploration. During the later sixteenth and early seventeenth centuries while the Spanish were consolidating and exploiting their New World empire, focusing on the mineral wealth of Mexico and South America, other European nations began to send explorers and adventurers to claim lands unoccupied by the Spanish. Most of the lands claimed by other European nations were in North America well removed from Spanish habitations and active opposition. The Frenchman Robert Cavalier, Sieur de La Salle commonly known as La Salle, ranged throughout the continent and eventually claimed the Mississippi River system for his king in 1682 .

During a return voyage to establish a French outpost at the mouth of the Mississippi, through a navigation error or other seventeenth century technological failure, La Salle ultimately landed on the Texas coast in the region of Matagorda Bay in 1685. Unfortunately, one of his three vessels, L'Aimable, wrecked at Pass Cavallo, the entrance to the bay. The other two vessels, La Belle and Le Joly, made it safely into the bay. The captain of the Le Joly had orders to carry supplies for the expedition and once his task was complete left for France taking several of the would-be colonists with him. La Salle was left with one ship, 180 people, and little idea of where he was. A camp called Fort St. Louis was made at the head of Lavaca Bay on the banks of Garcitas Creek. After several misadventures, including the loss of La Belle, La Salle decided to march with a small group of survivors to Canada so that a rescue mission could be organized, but he was murdered by his disgruntled men in March of 1687 (Bruseth and Turner 2006). La Salle's was an early failed attempt by Europeans to colonize Texas.

At Fort St. Lovis, La Salle had left hardly more than 20 persons with the crippled Gabriel
Minime, Sieur de Barbier, in charge. They consisted of women and children, the physically handicapped, and those who for one reason or another had incurred La Salle's disfavor. The Indians, learning of La Salle's death and the disunity among the French, attacked the settlement by surprise around Christmas 1688, sparing only the children (Weddle 2011).

The Spanish, jealous of their possessions and not wanting the French to establish a base, sent out an expedition to find and eliminate the threat that La Salle posed once they heard of it from a sailor named Denis Thomas, who jumped ship from the voyage and was ultimately captured while buccaneering. The Spanish found the wreck of La Salle's La Belle in early April of 1687 but did not locate Fort St. Lovis. It was a couple of years later when the Spanish became aware of the ultimate demise of the French at Fort St. Louis. Another expedition to the east Texas region was informed by the local Karankawa Indians that all the French were killed, and as proof the natives had many war trophies in the material possessions of the dead (Bruseth and Turner 2006). The wreck of La Belle is highly significant for its historical value and is listed among several early wrecks in the northern Gulf of Mexico region that have been archaeologically examined (Borgens 2011).

\subsubsection{Civil War}

During the American Civil War, the Union placed a naval blockade, quickly to be labeled the Anaconda Plan, almost immediately upon the seceding southern states. Unprepared for the war, the north could not establish an effective blockade immediately, but over time resources were developed and employed to strangle southern trade. The Confederate government did not have a well-developed naval or merchant marine infrastructure at the beginning of the conflict, nor did it have the resources to develop one. However, southern blockade runners had great success at the beginning of the war getting through the porous Union effort. Later in the war, when the Federal forces were more effective, and the laws of 
supply and demand were intensified, blockade running was a financial boon for successful ventures. As the Union Anaconda Plan began to be effective along the Atlantic coast of the Confederacy, the coast of Texas became more appealing to those who wished to move cotton out and various military and luxury goods into the Confederacy.

Texas, geographically at the western end of the Confederacy, was at the margins of strategic thinking, as the Mississippi River and the Atlantic Coast regions were initially focused upon. However, this did not inhibit the natives of the region from attempting to protect their shores and repel northern attacks and occupations. Although the port of Galveston and the Sabine Pass to the north were the sight of several major operations throughout the war, Matagorda Bay was also the scene of some belligerent activity. During the first months of the war, The Star of the West, famous in part for being fired upon by the Confederates in Charleston Harbor in January of 1861, was on another Federal mission to help evacuate northern soldiers from Texas. The Star of the West, chartered to carry Union baggage and supplies out of Texas, was captured in the waters of Matagorda Bay off Indianola by a small number of troops from Galveston using the vessel General Rusk on the 17th of April (Scharf 1996).

Matagorda Bay was entered by Federal gunboats as there were no real Confederate naval assets to stop them. Union vessels bombarded Indianola which was also briefly occupied and looted in the autumn of 1862. Just days later, Lavaca, a hub of military activity at the western edge of the Confederacy containing a Confederate arsenal and smallarms factory, was bombarded. Hosting several garrisons at various occasions throughout the war and having an active artillery battery, Union forces soon retired from the town. Late the next year, 1863, Union troops returned to occupy both towns. About six months later, in June of 1864, Federal troops evacuated the Matagorda Bay area (Malsh 2017; Maywald 2010). In addition to being the scene of minor naval engagements, other activities such as blockade running and commerce raiding took place in and from Matagorda Bay.

The Confederates used the tactic of commerce raiding throughout the war as they did not have the ability to produce naval vessels in quantity or quality to match the output of the North. Therefore, they tried to destroy northern commerce as they could not challenge the Union Navy. Near the end of the war, February of 1865, the Confederate privateer Anna Dale was waiting in Pass Cavallo for the remainder of her crew before she tried to slip the blockade to wreak havoc on Union shipping. Federal crews attempted to cut out the Anna Dale before she could make a cruise but ended up burning her when she grounded (Porter 1998). Thus, naval actions and maritime stratagems, although not central to the conflict, can be seen to have played out in Lavaca and Matagorda Bays from the beginning through to the end of the war.

\subsubsection{Post-Civil War}

After the Civil War, the bayside communities of Lavaca and Indianola rebuilt their infrastructure that was destroyed during the conflict. Railroads were rebuilt by both communities with service into the interior of the state to complement their shipping facilities. Competition between the two communities as a regional transportation hub appeared to favor Indianola. Unfortunately, the low-lying region was devastated by a hurricane in 1875 and again by the hurricane and fire of 1886. These tragedies devastated Indianola and the town was soon abandoned and Lavaca, to the north, began to prosper in its stead. Lavaca became the county seat in November of 1886. The next year a railroad service to Victoria and to the interior was reestablished and an era of growth began, and the town began to be known with the prefix Port (Malsh 2017; Maywald 2010).

\subsubsection{Twentieth Century}

Transportation developments changed the face of Port Lavaca. Cattle shipments, once a 
primary industry, were lost out to the railroad's expanding network. However, the railroad also created new opportunities. From the interior came a new commodity, tourists, people that would spend their resources enjoying the attractions of the bay. The bay also became a place of work as the federal government began waterway improvement projects such as dredging. In 1910, a channel was completed from Port Lavaca all the way to Pass Cavallo, the inlet at the Gulf of Mexico.

Three years later the Gulf Intra Coastal Waterway was completed giving Port Lavaca a protected water link to a major deep-water port to the north, Galveston. Fishing, in particular shrimping, became a leading industry for the region. Port Lavaca became a national leader in seafood shipments during the 1920s. This growth contributed to further expansions in the local infrastructure that affected the bay. A causeway was completed between Port Lavaca and Point Comfort in the 1930s. Additionally, gas and oil were discovered in the region during this period. Harbor improvements were also completed adding to an infrastructure that would attract business (Malsh 2017; Maywald 2010).

In the post-World War II era, large companies such as Alcoa, Union Carbide, Du Pont, and others established industrial facilities in the nearby communities. In 1953, residents 3.2 kilometers (2 miles) east of Port Lavaca, across Lavaca Bay, voted to become the county's third incorporated city, Point Comfort. By the early 1960s, the town was a mini industrial center supported by large aluminum plant and chemical industries. With the growing economic base, the need for access to better shipping infrastructure in the form of a deep navigation channel through Lavaca and Matagorda Bays to the Gulf of Mexico was recognized. Although hurricane Carla caused a large amount of damage in 1961, which ultimately lead to the causeway, a major transportation feature, being abandoned, the region persevered. In 1963, the Port of Port Lavaca-Point Comfort was designated a port of entry for customs purposes.
Two years later the deep-water channel from Point Comfort, with a side channel to Port Lavaca, known as the Matagorda Ship Channel (MSC) was completed (Malsh 2017; Maywald 2010).

As can be seen from the earliest days of Spanish exploration, through to the era of the Texas Republic and Civil War of the nineteenth century into the twentieth century, the waterways of Matagorda and Lavaca Bays have been utilized, and even depended upon, for transportation, communication, industry, and fishing. This robust utilization of the resource indicates that there may be resources of historical significance located beneath its waters. This is most strikingly illustrated by the recently located and removed seventeenth century ship La Belle, associated with La Salle's exploration and settlement activities in Matagorda and Lavaca Bay region. However, most of the historic activity took place along the western boundaries of the bays, while much of the development has taken place in the modern era.

\subsubsection{Lavaca Bay Communities}

Three cities in Calhoun and Jackson counties stand out today as being historically significant or as containing historically significant sites. These cities include Port Lavaca, Point Comfort, and Linville. A brief discussion of relevant historic period activities and of each city is provided below.

\subsubsection{Port Lavaca}

The modern city of Port Lavaca, originally known as Lavaca, is in the north central part of Calhoun County on the west coast of Lavaca Bay. The name comes from the Spanish adaptation of the French vache or cow, given to the area by French explorer René-Robert Cavelier, Sieur de La Salle for the sightings of Plains Bison, which were once common in the area (Maywald 2010).

The town was founded in the aftermath of the Linville raid of 1840, during which Comanche raiders attacked Victoria and Linnville. In the 
Republic period, Lavaca was the busiest port in the region and later, during the Civil War, it would house a large Confederate arsenal and small-arms factory. Among the city's historic points of interest are a historic lighthouse, hotels, churches, and cemeteries (Maywald 2010).

The Half Moon Reef Lighthouse was constructed in 1858 and was originally located in Matagorda Bay, at the southern tip of Half Moon reef. The beacon served as an aid to ships trading in Port Lavaca and the nearby town of Indianola. During the Civil War, the light was disabled by Confederate troops in an attempt to disrupt federal efforts to capture southern blockade-runners. The lighthouse was restored to full operation in 1868 and remained in service until 1943 when it was moved to Point Comfort. It was relocated to Port Lavaca in 1979 (Maywald 2010).

The Beach Hotel, constructed in 1904, has been a part of the Port Lavaca landscape for generations. At the time of its construction, the hotel was the tallest building in town, and tourists from inland cities often rode special excursion trains to Port Lavaca to enjoy the recreational opportunities along the coast and to stay in the hotel (Maywald 2010).

Historic churches include the First Baptist Church of Port Lavaca and the Saint Joseph Baptist Church. The First Baptist Church of Port Lavaca was organized in 1854 as the Lavaca Baptist Church. This congregation developed from area missionary efforts that began in the 1830s. Despite early hardships such as the Civil War, hurricanes, and a yellow fever epidemic, the Baptists continued their worship services and in 1913 were chartered by the state as the First Baptist Church of Port Lavaca. Active in the formation of several area congregations, the church has played an active role in the development of the town. The Saint Joseph Baptist Church began as the Free Will Baptist Church in the town of Indianola in 1872. Three years later, a devastating hurricane struck the Texas Gulf Coast, inflicting major damage on
Indianola. The congregation repaired their church, but in 1886, another hurricane destroyed the town. In 1898, the congregation purchased a warehouse in Port Lavaca and converted it for use as a house of worship. The name of the church was changed about 1900 to Saint Joseph Baptist Church. The original warehouse/church structure was replaced by a new building in 1984, and the church continues to serve the Port Lavaca community today (Maywald 2010).

Two historic cemeteries exist in Port Lavaca, the Ranger Cemetery and the Port Lavaca Cemetery. The oldest known grave in the Ranger Cemetery is that of Major H. Oram Watts, the customs collector at Linnville and casualty of the Comanche raid on that settlement in 1840. Other burials include Margaret Peyton Lytle, wife of James T. Lytle, the "poet" of the Texas Rangers. When an epidemic broke out during the Civil War (1861-65), a nearby house was used as a hospital. At least 10 federal soldiers were among victims buried here. Members of the five families who owned the site are also interred in Ranger Cemetery. The Port Lavaca Cemetery was in use in the 1840s, with several mass graves dating from an 1849 cholera epidemic. Pioneer families and their descendants, as well as prominent state, county, and city officials, are also interred in the community graveyard. At least one participant in the Battle of San Jacinto is buried here. Graves of both Union and Confederate soldiers may be found in the Port Lavaca Cemetery, which has been enlarged through various land transactions over the years to cover eight city blocks (Maywald 2010).

\subsubsection{Linnville}

Linnville is an early Texas port named for John Joseph Linn, an Irish pioneer merchant from Victoria who located his warehouse here in 1831. It is located north of Port Lavaca in Calhoun County. It was one of the most important ports of entry during the early period of the Republic of Texas. The site, originally named New Port, was later renamed Linnville, 
and grew to a population of 200 by 1839 . It was described as "a place of considerable business" in Sketches of Texas in 1840 and was used extensively during the early years of the Republic of Texas. Future San Antonio Mayor Samuel Maverick owned a warehouse in the town along with many other prominent Texans. The Federalist armies of Mexico used Linnville as an ordnance arsenal and depot during their attempt to defeat Centralist forces under the command of Antonio López de Santa Anna. These hostilities would give rise to the Linnville Raid of 1840, which was orchestrated by the Comanche Indians. Linnville was destroyed and eventually abandoned as Port Lavaca grew in prominence and much of the townsite of Lineville is now covered by Lavaca Bay (Roell 2015).

\subsubsection{Point Comfort}

Point Comfort is situated on the eastern shore of Lavaca Bay in Calhoun County. It was established in the early 1950s. In the 1960s, Point Comfort's economy was supported by a large aluminum plant and chemical industries due to its strategic location on Lavaca Bay and the easy access to the MSC (Texas State Historical Association [TSHA] 2019). Since the 1960s, the population of Point Comfort has steadily declined. In 1962, the town had a population of 1,453 residents. In 1972, the town consisted of 1,446 residents. The population in 1990 was 956 and dropped to 781 in 2000 (TSHA 2019).

\subsection{Maritime Context}

Researching the types of watercraft ubiquitous to the region throughout history can aid in the identification and temporal association of encountered shipwrecks and vernacular watercraft. Probing historic documentation of vessel losses is another avenue to assist in identifying submerged cultural resources reportedly lost within a specific area.

Various types of watercraft have been used to ply the waters of the Matagorda Bay, including Lavaca Bay and its associated rivers from the earliest prehistoric inhabitants to the modernday local residents and commercial enterprises. Vernacular watercraft were developed, constructed, and modified for use in the shallow lakes and bayous and shoaled, snag-filled rivers throughout coastal Texas, while sea-going vessels with deeper drafts were confined within a maintained navigation channel or dispersing their cargo among smaller vessels or boats for transport inland. During travel, vessels from prehistoric canoes to historic sailing vessels to steamboats were subject to overloading, foundering, snagging, collision, and even boiler explosion. As such, many vessels have been lost throughout the centuries in these waterways. Though there are no specific watercraft that are unique to the project area, a discussion of the types of watercraft that were used in and around the project area throughout prehistory and history and the requisite characteristics of each will be presented to demonstrate changes in morphology and continued trends that may be evident in the archeological record. A discussion of the types of watercraft known to have operated on the waters of Lavaca Bay is presented.

\subsubsection{Aboriginal Watercraft}

The dugout canoe represents one of the earliest forms of vernacular watercraft to ply the waters of the APE. Dugout canoes were utilized by the Karankawa and other indigenous groups moving inland during the winter and returning in the spring to exploit marine resources. The dugout canoe typically is a long, narrow, flatbottomed, double-ended vessel that could be paddled or rowed. Varying in size, larger canoes could carry several passengers and be laden with cargoes for transport from camp to camp along the inland rivers and the coasts (Lipscomb 2019). The early dugout canoe was constructed in a manner that involved felling of a tree and using fire and hand tools to burn and hollow out the log. Cypress was typically the wood of choice, though Native Americans in the region also used cottonwood (Comeaux 1985:164). Due to the lack of any potential magnetic components, the probability of 
identifying a dugout canoe buried beneath bottom sediments via remote sensing survey is low.

\subsubsection{Historic watercraft}

Although there are few specific accounts of the types of vessels used in Lavaca Bay and its associated drainages during the early historic period, it is likely that historic watercraft used on the Lavaca Bay and River were similar to those used on other western rivers and coastal harbors along the northern Gulf Coast. Gearhart (2017:Table 1) and Borgens et al. (2012:Table 1) provide samples of reported wrecks in Lavaca Bay which indicate some of the types of vessels that regularly plied the waters of the APE. These vessels include barges, schooners, sloops, luggers, and steamboats, as well as gas-powered vessels. The distinct characteristics of each are described below.

\subsubsection{Schooners}

The schooner is a type of sailing vessel whose name refers to its sail configuration and is typically a sharpbuilt vessel with two masts of considerable length and rake, a small top mast, and fore and aft sails. Its versatility allowed the schooner to operate in the open ocean, shallow bay waters, rivers, or inland lakes of southern Texas. Nineteenth-century schooners throughout the Gulf Coast typically measured 8.5 to 26.5 meters (28 to 87 feet) in length, while twentieth-century versions measured 14 to 23 meters (46 to 74 feet) in length (Saltus 1988:89).

Schooners can be further divided and specified according to type of rigging, function, or region of use. Originally rigged with square topsails, early schooners were referred to as topsail schooners. Later schooners were referred to as fore-and-aft schooners due to their rigging with Bermuda sails aligned fore and aft rather than squared to the masts (Saltus 1987:68). This variety was further divided into two, three, and four-masted schooners. When defined by their function, schooner types included: pilot schooners, trading schooners, fishing schooners, and packet schooners. Those defined by hull form included: scow schooners, barge schooners, pungy schooners, file bottom schooners, and ram schooners (Saltus 1988:90). Schooners defined by region of use included: Chesapeake Bay schooners, Great Lakes schooners, and Coastal schooners (Saltus 1987:68). Saltus argued that "the diagnostic attribute is the vessel's shallow draft and wide beam, dictated by the environment, depth, and functional need" (Saltus 1988:90). Further elaborating the variability in schooner size, a two-masted schooner had a typical size range of 7.2 to 26.8 meters (23.6 to 88 feet) in length, 3 to 7.5 meters (10 to 24.5 feet) in beam, and 0.8 to 2.9 meters (2.5 to 9.4 feet) in depth of hold (Saltus 1988:90).

While there are numerous schooners lost in the waters of Calhoun County, one example of a schooner lost in Lavaca Bay near Port Lavaca is the William \& Mary (THC Shipwreck No. 1001), which caught fire and sank in 1851. There is a moderate probability of discovering a historic schooner within the project area.

\subsubsection{Sloops}

The sloop, another versatile sailing craft, can be described as a vessel with one mast like a cutter but having a jib stay, which a cutter has not. Also, sloop is the general name of ships of war below the size of frigates (Brande 1856 as presented in Saltus 1987:71). Like the schooner, sloop also refers to sail configuration. Other varieties of the sloop include the sloopof-war, ship-sloop, brig-sloop, and corvette (Saltus 1988:92). Sloops were also capable of sailing in various environments including the narrow inland rivers and the open ocean. Their variability of size included typical ranges of 9 to 23.5 meters (30 to 77 feet) in length, 3.4 to 6 meters ( 11 to 19.67 feet) in beam, and 0.9 to 2.9 to 2 meters (6.42 feet) in depth of hold (Saltus 1988:92).

Review of the Atlas database indicates that there are two reported sloops in Calhoun County. The Prouty (THC Shipwreck No. 428) and a 
commercial vessel (sloop; \#01003) are both Texas State Antiquities Landmarks. The Prouty capsized and sank in 1886 at Indianola (Borgens et al. 2012:Table 1). There is no information available regarding the unidentified commercial sloop other than she beached at Indianola. Although there are no reported sloops lost near the APE, there is a moderate probability of discovering a historic sloop within the project area.

\subsubsection{Lugger}

The early lugger, whose name is derived from the rig of Mediterranean sailing boats, had rounded hulls and used centerboards (Pearson et al. 1989:198; Comeaux 1985:172). Employed as work boats for oystering and shrimping activities, luggers operated frequently in the shallow coastal lakes, bayous, and marshes as well as the deeper bays along the northern Gulf Coast. Construction of the boats was conventional consisting of sawn frames, carvel planking, and the usual plank keel of the centerboarder. The timbering and plank were often local longleaf pine and cypress (Pearson et al. 1989:198).

With the advent of the motorized lugger, older sailing luggers were surpassed in quantity and popularity. Motorized luggers, omitting the centerboard, allowed for rapid transport of fishing commodities to the market unlike the slower sailing luggers (Comeaux 1985:172). These luggers included a cabin to house the engine and operating controls. Motorized luggers appear typically as flat-bottomed, small craft, generally 6 to 9 meters (20 to 30 feet) long. More seaworthy luggers, of 12 to 15 meters (40 to 50 feet) length, were introduced later to access offshore oyster and fishing resources (Comeaux 1985:172).

An example of a historic lugger lost in Lavaca Bay near the APE is U \& I (THC Shipwreck No. 1947) which burned and sank in the 1920s (Gearhart 2017: Table 1). The probability of locating a historic and modern lugger in the project area is moderate.

\subsubsection{Steamboats}

Steamboats represent one of the most technologically innovative watercraft used in the nineteenth century, especially on the Lavaca River as well as Lavaca Bay. Propelled by steam engines, boilers, and paddlewheels, they were designated as side-wheelers or sternwheelers according to where the paddlewheel(s) were located on the vessel. Steamboats developed on the eastern rivers in the early nineteenth century, but rapidly spread throughout the western rivers (Pearson et al. 1989:107).

By the 1840s and early 1850s, the western river steamboat began to take the attributes of the classic riverboat. The most significant change during this time was hull design. Rounded hulls became less preferred to rectangular, singleframed hulls with either no keel or only a vestige keel (Pearson and Saltus 1993:15). The purpose of the hull design was to allow the transport as much cargo as possible and at the same time draw as little water as possible to allow maneuverability with sufficient speed in shallow water, as well as to reduce listing tendencies, a feature critical to steam power plant operation (Tuttle 2001:13). The most buoyant and stable hull was a duplication of the form of a flatboat; a long, flat bottom intersecting two short sides at right angles. Besides the stability, the cost of constructing a straight-lined hull with flat surfaces was more economically feasible than constructing one with the sheered lines of a sailing ship (Tuttle 2001:13).

After the Civil War, sternwheel propulsion became preferred over sidewheel propulsion. This attributed to the removal of the paddle wheel from its recess at the stern; the application of two engines to cranks fixed at right angles to each other at opposite ends of the paddle wheel shaft; the incorporation of the paddle wheel assembly in the hog chain system; and the introduction to the multiple balance rudder (Hunter 1949:172-173, as presented in Tuttle 2001:17). Cheaper to construct and more effective in shallower water depths than 
sidewheelers, sternwheelers became the most common vessel type by 1870 .

One such archaeological example of a steamboat that represents the type of steam vessels operating within the Lavaca River and Bay is the Mary Somers (41 JK9; THC Shipwreck No. 44) which sank in 1864. Although this vessel is located a substantial distance up the Lavaca River from the APE, it suggests that steamboat navigation in within the Lavaca River and Lavaca Bay was very frequent. While steamboat navigation was confined to established routes, as such, there is a low probability of locating steamboat remains within the APE.

\subsubsection{Post-Civil War and other Modern Craft}

Post-Civil War watercraft continued to utilize steam engine technology until they were gradually phased out by the invention of diesel and gasoline-powered motors. The slowmoving steamboats gave way to the towboats and barges for transporting large quantities of goods. According to Pearson et al. (1989:180), towboats and barges became the predominant mode of commercial freight transportation since the beginning of steamboating on western waterways (Pearson et al. 1989:180). However, railroads also played a significant role in the demise of the steamboat.

Modern watercraft in the coastal Texas region have evolved from the earliest vessels used in the expansion of the native and American populations and growth of commerce and industry. These vessels are often designated by terms that also refer to markedly different historic vessel types such as lugger, steamboat, or barge. As such, these vessels will not be described in detail as early watercraft forms were described above. Modern watercraft are used primarily for transportation of commodities and raw materials, pleasure craft, or participation in the seafood procurement industry throughout the project area. These vessels have typically abandoned the sailing rigging for motorized propulsion, though a few old-fashioned holdouts still remain. Modern watercraft include skiffs, john boats, yachts, and trawlers. However, there is a low probability that they may be discovered within the project area.

\section{Trawler}

In the early-twentieth century, the exploitation of shrimp as part of the seafood industry brought the motorized shrimp trawler to the fleets of vessels traveling to deeper waters in the Gulf of Mexico. Initially introduced by outsiders, the South Atlantic trawler, of 15 to 20 meters (50 to 65 feet) in length, was modified to become the shrimp trawler, a smaller version designed to trawl the bays and nearshore waters of the Gulf Coast (Comeaux 1985:172). Trawlers exhibit substantial forward sheer, high flaring bows with a nearly vertical stem, and broad, flat hulls. Larger versions, designed for deeper waters, are known as Florida-type shrimp trawlers. Trawlers are constructed of wood or steel and have been readily adopted to suit the needs of the seafood industry and the constraints of the environment. Though the deeper drafted Florida-type shrimp trawlers are found among the deepwater ports throughout the Gulf Coast, the smaller, coastally adapted trawlers are what operated within the project area. Despite the prevalence of trawlers employed in the seafood industry, there is a low probability of locating historic trawlers that have foundered or were abandoned within the waterways of the project area.

\subsubsection{Preservation of Submerged Cultural Resources}

The natural environment and human action are the two factors that directly influence the preservation of submerged cultural resources. The nature of the marine environment can aid preservation of wrecks or it can initiate rapid degradation of these fragile cultural resources. For example, changes in a river course can lead to complete burial and eventual land-locking of shipwrecks that originally were lost in riverine locations. Vessels abandoned along a riverine embankment can be filled with sediments or 
scoured by a high current. Storm surges from hurricanes also carry a high sediment load and are likely to bury historic shipwrecks lost within the project area under tens of feet of silt and sand forming a protective anaerobic environment. However, scouring actions from storm surges also can cause dispersal of hull fragments and artifacts along the bottom or allow the hull to settle lower and lower into soft bottom. Upon settling down to hardpan, though, the vessel then becomes subject to erosion.

Another environmental factor that is detrimental to the preservation of a shipwreck's wooden components and artifacts in saltwater environments is the naval shipworm (Teredo navalis), a species of wood consuming bivalve mollusks in the family Teredinidae. The bivalve is called a shipworm because it resembles a worm in general appearance. At the anterior end it has a small shell/mantle with two valves which are adapted to boring into wood. Degradation of wooden components is exacerbated by other marine organisms including the sheepshead (Archosargus probatocephalus), which destroys the already infested wood while foraging for teredo worms. Additional damage can result from stone crabs (Menippe mercenaria) which not only dismembers wood in search of inhabiting teredo worms but will also break apart ships timbers in an effort to create a nest or den.

Human action can cause as much destruction to historic shipwrecks as the above-mentioned environmental factors. Salvage activities remove valuable (and diagnostic) machinery and structural elements. Diagnostic artifacts can be disturbed or entirely removed from their context, which makes identification of a shipwreck much more difficult. Historic dredging and snag removal operations often destroyed and removed shipwrecks from the archeological record. Wake from passing vessels, both small craft and commercial boats, can create substantial wave action to dislodge fragments of wooden-hulled wrecks. Repetitive wave action against shallow or partially exposed wrecks will rapidly accelerate their destruction. Finally, looting is a recurring problem that dramatically affects the ability of the archaeologist to identify a shipwreck site. Often, diagnostic artifacts and vessel components such as bells, anchors, rudders, or propellers are removed by treasure seekers and souvenir hunters, thereby removing much of a vessel's identity. The above factors must be acknowledged when determining the likelihood of preservation of watercraft within the project area. The probability of preservation is high if bottom sediments buried vessels quickly. Preservation is low in areas where vessels lie exposed to the elements and human activities. Those vessels lost or abandoned near shore may have been picked clean by salvage, eroded by scouring, or damaged by repetitive exposure to boat wake.

\subsubsection{Navigational Improvements in Study Area}

Local waterways have been used for transportation, communication, industry, fishing, and war from the earliest days of Spanish exploration, through to the era of the Texas Republic, Civil War of the nineteenth century, and into the twentieth century. This long-term use has obvious implications for the discovery of shipwrecks and other submerged cultural resources in Lavaca Bay.

Review of available historical navigation charts revealed very few improvements within Lavaca Bay. Cartographic review revealed that there were no navigation improvements in Lavaca Bay until after World War II. The first evidence of navigation improvements is illustrated on the 1958 historic Matagorda Bay and Approaches navigation chart that shows a channel measuring 2.1 meters (7 feet) by 30.48 meters (100 feet) extending northeast across the current study area into the Lavaca River. Review of later navigation charts of the area indicates that the channel has been maintained but not widened or deepened since its first construction. Also, review of historical quadrangles suggest Lavaca Bay was developed by pipelines and 
various industrial enterprises serviced by the Lavaca Bay Channel and the dredged MSC by 1995 (NOAA 1958, 1995).

\subsection{Previous Cultural Studies}

\subsubsection{Site File and Literature Review}

Prior to field investigations, a desktop review was conducted that included a state site file search. Consulting the online Texas Archeological Sites Atlas database resulted in a listing of all recorded marine archaeological sites, shipwrecks, and National Register of Historic Places (NRHP) properties within 1.6 kilometers (1 mile) of the project APE. The site file research was used as a basis for developing a historical context and to gather information about past cultural resource survey activities near the project area. Background historical research incorporated material and data gathered during previous archaeological investigations and primary and secondary historical sources. The historical research aided in identifying potential types of marine resources that may have been deposited in the vicinity of the project area and determining the nature and extent of subsequent activities that may have removed or disturbed such resources. Data sources available for background research include historical maps, primary and secondary shipwreck lists, primary historical accounts, newspapers, the NOAA's Automated Wreck and Automated Wreck and Obstruction Information System (AWOIS) and Electronic Navigational Charts (ENC), the THC online Atlas databases, and county and thematic histories. Information gleaned from these sources aided in developing a list of potential resources as well as identifying resources that may be expected to be located within the project area.

\subsubsection{Reported Shipwrecks in Study Area}

A review of NOAA's Office of Coast Survey Wrecks and Obstruction Database, which is sourced from NOAA's AWOIS and ENC did not identify any wrecks within the project APE or the 1.6-kilometer (1-mile) study radius of the APE.
Three known wrecks, $U$ and I and two Unknown, are located just outside the study radius (Figure 3-1, Table 3-1) (THC 2019a, b, c).

Table 3-1. Wrecks Reported within Lavaca Bay.

\begin{tabular}{|c|c|c|c|}
\hline Name & $\begin{array}{c}\text { THC } \\
\text { Number }\end{array}$ & Date Lost & Description \\
\hline$U$ and I & 1947 & 1920 s & Lugger \\
\hline Unknown & 1235 & Pre-1970 & - \\
\hline Unknown & 1238 & Pre-1970 & - \\
\hline
\end{tabular}

\subsubsection{Previous Cultural Resources Surveys}

Previous marine investigations have included numerous surveys conducted between 1993 and 2018 in advance of petroleum and navigation enhancement projects. According to a search of the Texas Archeological Sites Atlas, two previous cultural resource surveys are located within the project APE (Figure 3-1). In 1993, Coastal Environments Inc., under contract to the USACE, conducted a marine remote sensing cultural resources survey of the navigable portions of the Lower Navidad and Lavaca Rivers in Jackson County utilizing a magnetometer and side-scan sonar. The survey resulted in negative findings (Pearson et al. 1993).

In 2016, Surveys and Mapping, LLC (SAM) conducted a marine archaeological survey of the proposed West Ranch to Point Comfort Pipeline Project under Texas Antiquities Permit 7431. The survey area is located in the upper portion of Lavaca Bay, north of the Lavaca Bay Causeway. The APE, which intersects the current APE, measured 7.1 kilometers (4.4 miles) long; 610 meters $(2,000$ feet) wide at the north end; 1,524 meters $(5,000$ feet) wide at the south end; and encompasses 659 hectares $(1,628$ acres). A total of 22 magnetic anomalies (Mag 1 to Mag 22) and a charted area of periodically exposed wreckage were identified. All 22 anomalies and the charted wreckage are potentially associated with historic shipwrecks and could meet criteria for State Antiquities Landmark status or for the NRHP. These were recommended for avoidance by bottomdisturbing activities associated with this project 
REMOVED FROM PUBLIC COPY

NOAA AWOIS, ENC, and THC reported shipwrecks and previously recorded surveys and sites within and just outside a 1.6-kilometers (1-mile) study radius of the project area. 
(Gearhart 2016). The avoidance boundaries, as mandated by the Texas Administrative Code, Title 13, Part 2, Chapter 26, of three magnetic anomalies (Mag 7-Mag 9), consists of a 50meter (164-foot) buffer, surrounding the extents of the target, are partially located within the current APE.

In 2017, BOB Hydrographics, LLC (BOB). BOB conducted a marine archaeological survey, performed under Texas Antiquities Permit 8004, on May 31, 2017, of a proposed oyster reef restoration site in Lavaca Bay, Texas. This project is located just outside the study radius. It was sponsored by the Texas Parks and Wildlife Department and spans portions of State Mineral Lease Tracts 17A and 20A in Calhoun County. A total of 20 hectares (50 acres) was surveyed, including a 50-meter (164-foot) buffer around the APE. The survey resulted in the discovery of one target potentially eligible for the State Antiquities Landmark or for the NRHP. Anomaly 1 is recommended for avoidance (Gearhart 2017:iv).

3.4.1.3 Previously Recorded Archaeological Sites

According to a search of the Texas Archeological Sites Atlas and literature review, there are no previously recorded sites within the APE; however, there are three previously recorded unidentified magnetic anomalies, identified as Mag 7, Mag 8, and Mag 9, that are partially located within the APE that represent significant cultural resources. These anomalies were recorded in 2016 during the marine archaeological survey of a proposed pipeline that intersects the current APE by SAM (Texas Antiquities Permit 7431). None of the three magnetic anomalies have a corresponding sonar contact. Avoidance area and 50-meter (164-foot) buffers were developed for each (Gearhart 2016). Mags 7, 8 , and 9 are described below.

Mag 7 is described as an unidentified magnetic anomaly with a positive 171-gamma and a negative 15-gamma deflection measuring 30.2 meters (99 feet) in diameter, located in 1.7 meters (5.7 feet) of water (Gearhart 2016: Table B2). Gearhart developed a 50-meter (164-foot) avoidance buffer for Mag 7, which extends 17.7 meters (58 feet) into the current APE (see Figure 3-1).

Mag 8 is described as an unidentified magnetic anomaly with a positive 115-gamma and a negative 22-gamma deflection measuring 30 meters (97 feet) in diameter, located in 1.5 meters (4.9 feet) of water (Gearhart 2016: Table B2). The 50-meter (164-foot) avoidance buffer for Mag 8 extends 25.6 meters (83.6 feet) into the current APE (see Figure 3-1).

Mag 9, which is located 32.5 meters (106.7 feet) east from Mag 8, is described as an unidentified magnetic anomaly with a positive 1,278-gamma and a negative 71-gamma deflection measuring 30.48 meters (100 feet) in diameter, located in 1.5 meters (4.9 feet) of water (Gearhart 2016: Table B2). The 50-meter (164-foot) avoidance buffer for Mag 9 extends 13.6 meters (45.7 feet) into the current APE (see Figure 3-1).

There is one previously recorded site, 41CL88, located within the 1.6-kilometer (1-mile) study radius of the project area (Figure $3-1$ ). There is no information regarding cultural component or site dimensions provided in the site file (THC 2019d).

\subsubsection{Previously Recorded Historical Markers}

Review of the Texas Archeological Sites Atlas database also revealed there is one historical marker located within 1.6 kilometer (1 mile) of the study corridor in Calhoun County. It is the Site of the Town of Linnville (Atlas Number 5057003091). It was established in 1936 and consists of a Centennial Marker (gray granite) located 2.9 kilometers (1.8 miles) west of State Highway 35 in Port Lavaca. The text reads "An early Texas port named for John Joseph Linn 1798-1885 A pioneer merchant of Victoria who located his warehouse here in 1831 Around this 
a settlement grew up which was destroyed by Comanche Indians on August 8, 1840 Erected by the State of Texas 1936" (THC 2019e).

\subsubsection{National Register of Historic Places}

The NRHP database for Calhoun and Jackson counties was consulted and revealed that there is no NRHP-listed property situated within the APE or within 1.6 kilometers (1 mile) of the APE. The database review revealed that there is one NRHP-listed property located in Calhoun County, the Matagorda Bay Lighthouse (Ferguson 1984).

The Matagorda Bay Lighthouse (1850-1899; NPS no. 84001624; listed in 1984) was constructed by the U.S. Coast Guard Lighthouse Service in 1851 (Ferguson 1984). It is located west of Pass Cavallo, 41.29 kilometers (25.65 miles) east-southeast of the APE.

Research also revealed that there are three NRHP-listed properties in Jackson County (NRHP 2019). Two are standing structures, and one is an archaeological site. They were listed on the National Register between 1979-2011. The two structures, Texana Presbyterian Church (1850-1924; NPS no. 79002982; listed in 1979) and the Edna Theatre (1950-1974; NPS no. 11000652; listed in 2011), are located 32.51 kilometers (20.2 miles) west-southwest of the APE (Freeman et al. 1979; Condron 2011).

Lastly, the third NRHP-listed property is an archaeological site, 41JK9, also a State
Antiquities Landmark (Atlas No. 820000117), consisting of the remains of the sidewheel steamship Marry Summers (1849-1874; NPS no. 94000833; listed in 2011). It is located within the Navidad River near the City of Lolita in Jackson County, approximately 14.55 kilometers (9.04 miles) north-northeast of the APE (TxGLO 1994).

A brief mention should be made of the La Belle shipwreck. Although the wreck site is well outside the project area, its historical importance to the region warrants a mention here. It had long been known that La Salle's illfated mission had lost two ships in the vicinity of Matagorda Bay; L'Aimable, near Pass Cavallo, and La Belle along the Matagorda Peninsula. In 1978, the first magnetometer survey was conducted in high probability areas in both locations by both boat and helicopter. However, limits in positioning technology limited the results (Bruseth and Turner 2005). In 1995, a new survey was conducted making use of improved GPS technology. Thirty-nine targets were identified, including what turned out to be the remains of La Belle (Arnold 1996). Difficult diving conditions and the historical importance of the wreck resulted in the decision to excavate within a cofferdam. A treasure trove of artifacts was recovered: cannon, firearms, pottery, glass, as well as nearly half of the ship's hull (Bruseth and Turner 2005). More recent research indicates that approximately one third of the hull remains were recovered (Carrell 2017). 


\subsection{FIELD METHODOLOGY}

\subsection{Field Methods}

Field investigation of the project consisted of an intensive marine survey. The underwater survey employed a variety of remote sensing technologies deployed from a survey vessel to examine the bays' beds and locate anomalies and acoustic targets on or buried in submerged sediments that might be affected by project activities.

\subsubsection{Underwater Archaeological Survey}

The survey vessel used for the present project was BIO-WEST's 8.2-meter (26-foot) aluminum work vessel (Figure 4-1). The vessel's attributes (ample deck space, shallow draft, high maneuverability, davits, and winches) made it an excellent platform from which to conduct the survey while towing numerous pieces of gear. The vessel was propelled by two 130. horsepower (HP) outboard motors and has a top speed of 25 knots to transit to the survey site, while a survey speed of approximately 4 to
5 knots could easily be obtained. The onboard 5-kilowatt power system provided more than enough electricity to power all the remote sensing equipment, computers, navigation gear, deck hoists and winches, and safety equipment.

Positioning is considered a critical aspect of marine remote sensing projects. There are few landmarks on the water to use for orientational reference. In order to recreate or relocate survey targets, accurate positioning is critical. For navigation and positional control, BIO-WEST utilized a Hemisphere ${ }^{\circledR}$ VS110 differentially corrected global positioning system (DGPS) receiver. Vessel guidance, position, and data logging was accomplished with a navigation processor utilizing Trimble ${ }^{\circledR}$ HYDROpro ${ }^{\text {TM }}$ Navigation software. Positional information for the survey vessel and each instrument sensor, via layback calculations, was stored in the navigation processor at a rate of one reading per second. The navigation system was the basis around which the survey was built.

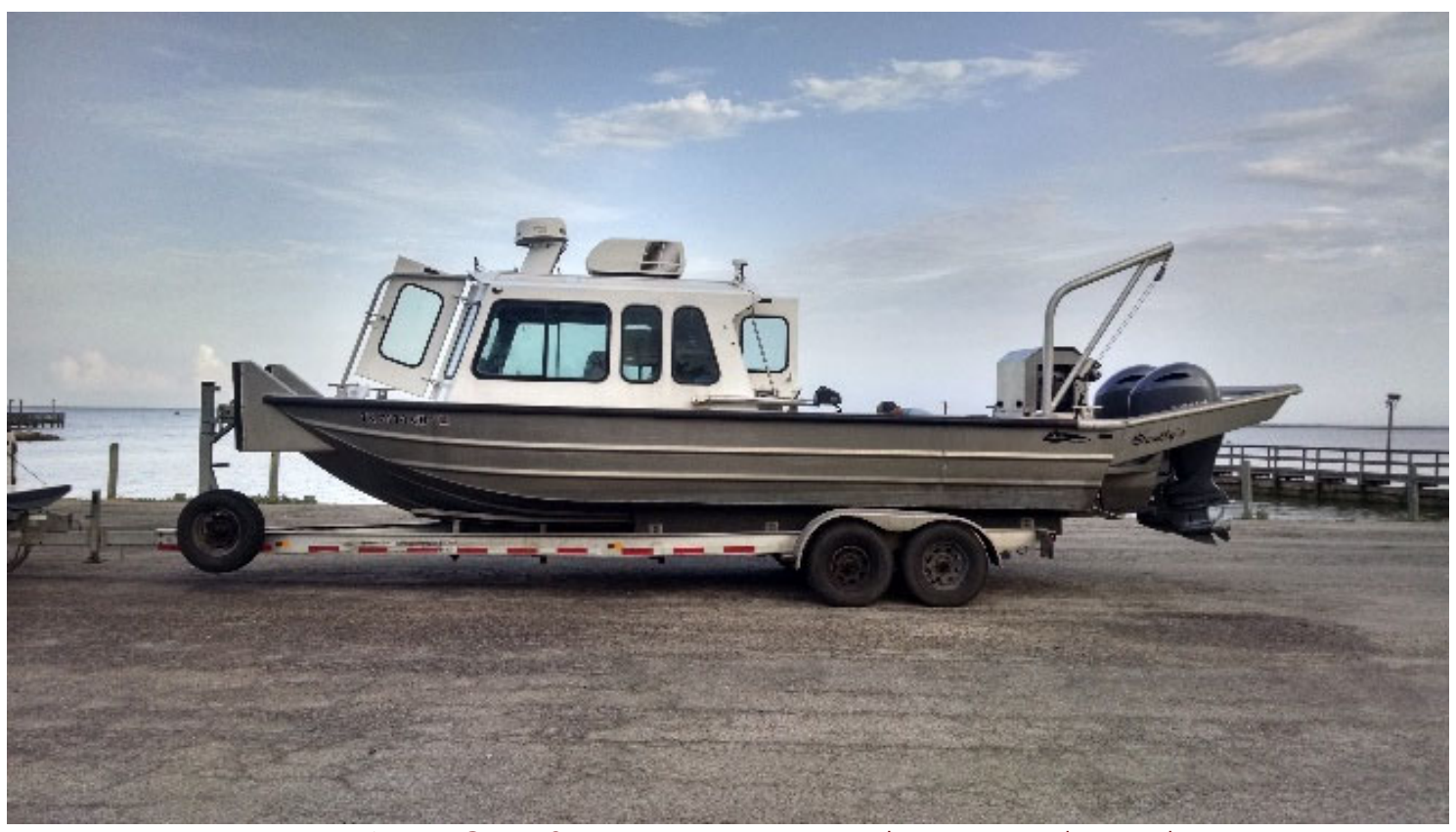

Figure 4-1. BIO-WEST's project survey vessel. View is to the south. 
Project area coordinates and pre-plotted survey lines were pre-programed into the computer. The onboard computer converted positioning data from the DGPS receiver to NAD 83, Zone Texas South Central in U.S. Survey feet, in real time that were established at 20-meter (65-foot) offsets. These coordinates were then used to guide the survey vessel precisely along the predetermined track lines (Figure 4-2). While surveying, vessel positions were continually updated on the computer monitor to assist the vessel operator, while the processed easting and northing data were continually logged to the computer storage disk for post-processing and plotting. All survey lines were positioned down the pre-plotted tracklines that had the general orientation of southwest northeast. All areas were safely navigable, and the project area fully covered.

To examine the seabed, an EdgeTech 4125 dual frequency all digital side-scan sonar system was used. The dual frequency, 400/900 kilohertz $(\mathrm{kHz})$, side-scan sensor collected and gave a real time display of the acoustic data throughout survey operations. Due to the shallow waters of the bay, the sonar towfish was deployed from the port side of the survey vessel 0.5 meters ( 1.6 feet) deep in conjunction with a pole mount and side bracket, in an effort to obtain the most diagnostic acoustic images of the bay bottom. The sonar unit was operated at a 50-meter (164-foot) range to provide comprehensive overlapping coverage and detail of the project area. The EdgeTech system collected both acoustic data with real-time positioning data that were merged for post processing and analysis.

Magnetic data were collected with a Geometrics G-882 cesium magnetometer. The marine magnetometer's operating principal is based on self-oscillating split-beam cesium vapor, with an operating range of 20,000 to 100,000 nano-tesla (nT) and a counter sensitivity of $0.004 \mathrm{nT}$. The survey areas were in waters approximately 1 to 5 feet $(0.3$ to 1.5 meters) deep in Lavaca Bay. Due to the shallow waters of the bay, the magnetometer sensor was floated at the surface and towed 16.8 meters (55 feet) behind the survey vessel to prevent any magnetic interference from the survey vessel. Magnetic readings were recorded at a rate of 1 per second. The magnetometer could detect, if present, ferrous-based objects indicative of steel pipelines or "metal" debris below the vessel track line. If the sensor passes materials below, on, or projecting above the seafloor containing ferrous metal masses or magnetic properties large enough, fluctuations created within the earth's local magnetic field would be recorded. Fluctuation is measured in gammas or $\mathrm{nT}$ and proportional relative to the distance of the sensor to the mass of ferrous metal contained in the sensed object. Due to the relative proximity of the bay bed to the sensor, it is considered that any anomaly observed would generally be represented as larger than if the sensor was flown at a traditional survey height above bottom of approximately 6 meters (20 feet).

\subsubsection{Data Products- Side-scan Sonar}

The side-scan sonar derives its information from reflected acoustic energy that is recorded onto a desktop survey computer. Side-looking sonar transmits and receives swept high frequency bandwidth signals from transducers mounted on a sensor that is towed from a survey vessel. Two sets of transducers mounted in an array along both sides of the towfish generate the short duration acoustic pulses required for highresolution images. The pulses are emitted in a thin, fan-shaped pattern that spreads downward to either side of the towfish in a plane perpendicular to its path. As the fish is towed along the survey trackline, this acoustic beam sequentially scans the bottom from a point beneath the towfish outward to each side of the trackline. 
REMOVED FROM PUBLIC COPY

Planned and actual survey track lines for the Webster to Seadrift Pipeline project area, Calhoun and Jackson counties, Texas. 
Acoustic energy reflected from any bottom discontinuities (exposed pipelines, rocks, unexploded ordnance, or other solid submerged objects) is received by the set of transducers, amplified, and transmitted to the survey vessel via a tow cable. The digital output from units is essentially analogous to a high angle oblique photograph providing detailed representations of bottom features and characteristics. Sonar allows display of positive relief (features extending above the bottom) and negative relief (such as depressions) in either light or dark opposing contrast modes on a video monitor. Additionally, reflectivity of bottom sediments can indicate transitions between harder and softer seabed materials. Examination of the images thus allows a determination of significant features and objects present on the bottom within a survey area.

Side-scan sonar data present a near photographic presentation of an area examined from reflected sound. Sonar images capture only what is above or on the seabed, and in some cases can discriminate between various densities of seabed. However, any buried material that does not affect the surface of the seabed in any way cannot be discerned. In some ways, the analysis of side-scan sonar data is relatively easy; one sees what is observable. Interpreting the nuances of side-scan sonar records is another matter. Characteristics of an acoustic target to be scrutinized in a sonar image are spatial extent, association or configuration, location, and the environmental context. Shipwrecks are generally easy to discern as are other large, regular, articulated cultural features. Additionally, many natural features, rock outcrops, oyster reefs, sunken logs, and even schooling fish create images that can be identified in the data. The difference between a log and a length of pipe are a bit harder to make based solely upon side-scan data; however, in conjunction with other remote sensing technologies and knowledge of the local environment, interpretive determinations of the created images can be soundly made.
Sonar records were inspected for potential manmade features and obstructions present on the bottom surface. Sonar data were saved in individual files for each survey lane. Individual acoustic data files were initially examined John Rawls of Gray and Pape using Edge Tech's Discover 4200-SP Dual Frequency Side-Scan Sonar Software to identify any unnatural or man-made features in the records and SonarWiz was used to create the final mosaic. Acoustic targets are normally defined according to their spatial extent, configuration, location, and environmental context.

\subsubsection{Data Products-Magnetometer}

The Geometrics G-882 Marine Magnetometer measures the earth's ambient magnetic field strength at the sensor's location. Although the earth's magnetic field does change with both time and distance, over short periods and distances the earth's field can be viewed as relatively constant. The presence of magnetic material and/or magnetic minerals, however, can add to or subtract from the earth's magnetic field creating a localized magnetic anomaly. Rapid changes in total magnetic field intensity, which are not associated with normal background fluctuations, mark the locations of these anomalies.

Magnetic data were collected utilizing Hypack hydrographic software and were edited for detailed analysis and to create a magnetic contour map. Magnetic data were refined prior to the review of raw data (of individual survey lines) to delete any artificially induced noise or data spikes. After all the survey lines for each area were edited, data were converted to an $X Y Z$ file (easting and northing coordinates in Texas [South] State Plane [NAD83], and magnetometer data - measured in gammas). Magnetic data were then analyzed using Microsoft Excel by John Rawls, under the supervision of Michael Tuttle. When graphically represented by generating a magnetic contour map, anomalies can easily be plotted out in the project area. 


\subsubsection{Remote Sensing Interpretation- Magnetometer}

The magnetometer and side-scan sonar are the basic tools of marine archaeology. The magnetometer can indicate metal objects, which are some of the main components of shipwrecks, while the side-scan can create a near photographic image of the seabed that allows for detailed analysis of recorded objects. Unfortunately, the analysis and interpretation of remote sensing data is a process that is not 100 percent accurate in identifying a target source. While a physical examination is the only way to positively identify the source of a remote sensing target, in most cases it is economically unfeasible to examine every recorded anomaly. Therefore, a rational method has to be used to discriminate the likelihood that a magnetic anomaly source or side-scan sonar image represents a potentially significant cultural resource. Numerous factors should be considered while interpreting remote sensing data.

The factors that make up the basis for remote sensing interpretation are just as important as quality data acquisition. Magnetometer data present several properties which can be used for analysis. One characteristic examined is magnetic amplitude, or the deviation recorded from background readings. The change from background may be either positive or negative or both. If the amplitude change is only in a single direction, it is known as a monopole. Monopoles are characterized by anomalies exhibiting either a positive or negative deviation from the ambient magnetic field. Monopoles often are formed by non-ferrous geological features and/or linear objects such as pipe or long rods where only one end is detectable with the magnetometer. If a magnetic anomaly has a single positive and negative change it is a dipole. The dipole normally is oriented along the axis of magnetization, with the negative portion located nearer the north pole of the source object. The positive portion of the anomaly commonly is of greater intensity than the negative portion.
If the anomaly source has more than two opposing peaks, it is complex. Historic shipwrecks, which often contain numerous ferrous objects, usually produce complex magnetic signatures comprising multiple dipole and/or monopolar anomalies. This class of signature is particularly apparent when the wreck is scattered and dispersed.

Another significant characteristic for analysis is the anomaly's duration and how long it occurs in the record. Again, an anomaly is a local event, and the closer the sensor is to its source, the greater the amplitude recorded. Within this local field, the recorded duration will increase from and die out to background readings where it is no longer detected by the sensor. Duration of an anomaly is measured in either time or distance. Time indicates the total number of continuous seconds that an anomaly was recorded during survey. This measurement, however, can vary in relation to the speed of the survey vessel. Distance, on the other hand, indicates the linear distance along a survey line that an anomaly was detected and is not influenced by the speed of the survey vessel. One other factor that must be considered when interpreting magnetic data is the proximity of the towfish to the anomaly. As a rule, the strength of an anomaly is proportional to the inverse cube or square (depending on orientation) of the distance between the source and the point of measurement. Because of this rapid decline in anomaly strength, objects near the sensor are more likely to produce marked variation in magnetic intensity than are more distant objects (Breiner 1973). This can be of significant concern during marine magnetometer surveys, during the course of which the magnetometer towfish may "fly" at different depths in the water column. When combined with changes in water depth throughout a waterway, predicting the size and identity of an anomaly or group of anomalies without corroborative visual evidence can be extraordinarily difficult. Also, objects that are deeply buried may be recorded as smaller intensity anomalies due to their distance from the towfish. 
When considering size, character, and duration together, a baseline for interpreting magnetic data is created. With this in mind, some generalizations of magnetic data can be made. Anomalies exhibiting a short duration often indicate small objects or modern debris that has not been present long enough to alter the ambient magnetic field other than immediately around it. Anomalies with a longer duration often indicate larger objects or features that have been in situ for decades or centuries and have gradually expanded the distance of magnetic disturbance from the source over the ambient field. This, of course, depends upon the magnetic intensity of the anomaly and the proximity of the towfish to the original source when detecting it. An anomaly that registers a moderate intensity over a longer distance, with a gradually fluctuating signature, can indicate a deeply buried object or an older magnetic anomaly, and perhaps a historic cultural resource. For example, the magnetic signature of a nineteenth century steamboat, which would have a substantial amount of iron components lying upon the surface of a river bottom in 6.1 meters (20 feet) of water will certainly differ from that of a similarly sized steamboat deeply buried in 6.1 meters (20 feet) of riverine sediments.

Another attribute of an anomaly that has been receiving more attention in analysis lately is its orientation, the way the poles of the anomaly are oriented relative to the earth's magnetic field. During the present field research, it must be noted that the sensor was held approximately 0.3 to 1.5 meters ( 1 to 5 feet) from the seabed. Magnetic deviation recorded is, in part, a function of distance between the sensor and magnetic source material. For example, the closer the sensor to the material, the larger the reading.

Effective analysis of magnetic remote sensing data depends on quality data collection, knowledge of the environment from which the data are collected, and experience with examining anomaly sources. Through the years, several authors have created models to aid in interpreting remote sensing data, especially magnetometer data. Garrison et al. (1989) created an early model based on selected shipwrecks in the Northern Gulf of Mexico. The authors suggest that a magnetic signature for the vessels' remains they examined would cover an area of between 10,000-50,000 meters squared (107,639-538,195 square feet). That converts to an area between approximately 100 by 100 meters (328 by 328 feet) to 223 meters by 223 meters (733 by 733 feet), or put in another way, 1-5 hectares (2.47-12.35 acres). These are rather large areas and do not appear to be representative of smaller, wooden vessels that would be of great interest to historians and archaeologists. History has indicated that this model, although a good early start as a baseline for analysis, could be refined.

Later, Pearson et al. (1991), considering the earlier work, developed a new model in order to suggest the presence of shipwrecks based on observed magnetic amplitude and duration of a known sample of shipwreck sites. Threshold data for potential shipwreck sites were set at 50 gamma total magnetic deflection from background with a linear duration of greater than 24 meters (80 feet). Notice the duration is greatly decreased, and a minimum element of magnetic deflection is introduced. Recently, Linden and Pearson (2014), "recognizing a considerable amount of variability," have revised Pearson's initial quantitative measurements downward to eliminate targets with magnetic signatures of 50-gamma deflection and less than 20-meter (65-foot) duration (Linden and Pearson 2014). In addition to these quantitative limits, Pearson with Hudson (1990) have argued for a qualitative assessment of remote sensing data as well.

Several models have been created and refined to aid in the interpretation of magnetic data based on quantitative data relative to aid in the identification of potentially significant shipwreck sites. Another important aspect of remote sensing data interpretation is the context in which a survey was conducted, as argued by Pearson and Hudson (1990). It is important to 
understand and consider the variables that may contribute to the archaeological record; from debris deposition through to various seabed/shoreline modifying activities as well as construction.

Other factors, besides the apparent success of the 50 -gamma/80-foot criteria must be considered for interpretation of magnetic anomalies. Specifically, the cultural and environmental context in which an anomaly is located must be taken into account. As such, for areas that have been historically used and/or are currently used for commercial and industrial activities, a substantial amount of modern debris scattered throughout the project area must be anticipated. This modern debris and/or submerged energy infrastructure (i.e. pipelines), depending on their magnetic intensity, can create disturbances in the ambient magnetic field that resources nearby could be masked and rendered undetectable. Any cultural resources, such as shipwrecks, located nearby would be essentially invisible to the magnetometer alone due to extreme background magnetic interference. This is easily recognized on contour maps of the survey segments as numerous closely spaced magnetic contours creating virtual blotches. Other methods to assist in interpretation of magnetic anomalies and detection of cultural resources include correlating magnetic data with acoustic data. Magnetic data, compared with sonar data, can occasionally determine whether an anomaly represents a shipwreck site or a scatter of modern debris.

A study in a context very different from the present research, Boston Harbor, examined 67 previously identified remote sensing targets. The historic importance of the water body to American history cannot be discounted. The examination found approximately 15 percent of the initially identified materials were mobilized and could not be recreated; the sources for the remaining targets were identified. The materials examined spanned the gamut from metal debris, pipes, and chain to fishing gear and several watercraft. Four barges, one modern vessel, and the remains of a potentially significant wooden hulled shipwreck were observed. In the context of a harbor that has had historic traffic and is still actively used today, only one potentially historic site was located (Tuttle 2004). Locating one potentially significant site indicates the rarity and difficulty of distinguishing remote sensing data as significant archaeological sites. However, it also indicates the necessity to examine anomalies in the proper context to ensure that the rare sites that are indicated in the record are protected.

The present project area's environment consists of relatively shallow areas within Texas' bays. Maritime activity within the Gulf Intracoastal Waterway, which exists in proximity to the survey areas, allows access to and through the bays. Besides commercial vessels transiting the areas, recreational vessels are also common in the bays. Additionally, the proposed pipeline route is adjacent to three existing pipeline right-ofways (ROWs). These environmental factors should be taken into consideration while conducting an analysis of the project anomaly data.

A third model, which has been more recently developed, does not rely exclusively on a specific magnetic deflection or area of coverage, but on the very essence of the earth's magnetic field and the orientation characteristics of a recorded magnetic anomaly. In order to increase the efficiency of magnetic analysis as "Only a tiny fraction of seafloor magnetic anomalies are associated with shipwrecks," Gearhart (2011:91) has created a model for identifying shipwreck sites based, in part, on the principles of magnetic orientation. Using 29 known shipwreck sites comprising a varied selection of vessel types exhibiting a wide range of horizontal dimensions and magnetic amplitudes, the basis of other magnetic interpretive models, Gearhart highlights the orientation of the represented anomaly itself, an overall dipole configuration. One unique magnetic characteristic of all known shipwrecks in the sample presented has 
to do with the magnetic orientation of the anomaly; on examination, it can be recognized that the negative component of a dipolar anomaly unfailingly resides to the geographic north. Additionally, it is recognized that the magnetic deviation of the graphically represented signature did not vary greater than $26^{\circ}$ from magnetic north (Gearhart 2011). Thus, a dipolar anomaly with a positive gamma deflection to the north is not consistent with known shipwreck sites and therefore should not be considered a potential shipwreck. The smallest shipwreck located by this method is known as Site 41CL92 (THC 2019f; Atlas Number 9057009299). The magnetic anomaly for this site had a total magnetic deviation of 191 gammas made up of a positive and negative component and could be detected over an area of 1,580 square meters ( 0.4 acres) at a 5-gamma interval. The site, when examined by divers, measured roughly 7 by 16 meters (23 by 52 feet) and is thought to be the remains of a nineteenth century sailing vessel (Gearhart $2011)$.

Interpreting the context of an archaeologically surveyed area relative to remote sensing analysis is the grayest of the evaluation criteria. There are no baseline numbers or qualitative assessments to be referred to or consulted. Experience and in some respects common sense are required to make a subjective evaluation based upon the variables pertaining to the environment worked in. The only way to know the source of every magnetic anomaly or sidescan image is to have a complete examination either by an archaeological diver or remotely operated vehicle. "Hands-on inspection of every buried anomaly source may not be an economic possibility, so researchers must trust their interpretive abilities" (Gearhart 2011). In the context of the present research, the environmental and historic considerations will be one of the factors considered while interpreting for potential significance of the sources of magnetic anomalies.

For the present investigation, in the shallow bays of Texas where there has been considerable development and use, utilizing the abovementioned methods to filter anomalies to determine potential significance is considered prudent, as every anomaly is not a shipwreck. The main filter employed is the model developed by Gearhart (2011). Any anomaly that contains a positive magnetic deflection to magnetic north, in an overall dipole representation, was not considered potentially significant and thus removed from consideration of potential significance. Also, any anomaly that did not fit the minimum quantitative and orientation criteria, as expressed in Site 41CL92, amplitude, area of coverage, negative pole to the south, was not considered potentially significant. Small, single point sources were not considered significant either. 


\subsection{RESULTS OF INVESTIGATIONS}

\subsection{Results of the Remote Sensing Survey}

The grid for the remote sensing survey within the open waters of the bay consisted of a total of 19 track lines (Lines 1-16, 18, 19, 37, and 38) at 20-meters (65.6-foot) line spacing oriented parallel to an existing pipeline ROW (see Figure 4-1). The remaining portions of the project area within Lavaca River and Catfish Bayou were surveyed at 20-meter (65.6-foot) line spacing (Lines 0, 17, 22-35, and 39-43) oriented perpendicular to the survey corridor. A combined total of 284.6 kilometers (176.9 linear survey miles) were transected utilizing the magnetometer and side-scan sonar encompassing an area of 391 hectares (967 acres). A total of 127 individual magnetic anomalies were recorded and a total of two acoustic targets (SST1 and SST2) were recorded within the survey corridor. The results for the magnetometer and side-scan sonar survey are described below.

\subsubsection{Magnetometer Results}

The ambient magnetic field of the overall project area is approximately 46,400 gammas. The 127 magnetic anomalies range from 5 gammas to 14,918.2 gammas. All recorded anomalies were organized by their respective survey line and sequentially numbered. The position, magnetic signature, duration, and interpterion of each magnetic anomaly are presented in Table 5-1. 10-gamma contour maps of the project area are presented on a color scale where red represents positive and blue represents negative (Figures 5-1 to 5-6). Magnetic data recorded for the current survey were analyzed and interpreted based on the Pearson and Linden (2014) 50 -gamma/65foot criteria and the Gearhart 2011 model, which have been established over numerous cultural resources remote-sensing surveys. Data collected along survey Lines 9-12 were deemed too "noisy" to be reviewed for cultural resources due to the proximity of the existing pipeline. The magnetic profiles of these lines exhibit a continuous, linear magnetic anomaly consisting of both very high and very low magnetic signatures that extends the length of the survey area (see Figures 5-1 to 5-6).

Of the 127 magnetic anomalies, 80 anomalies meet or exceed the 50-gamma/65-foot criteria in which 43 are associated with existing pipelines (Table 5-1). While the remaining 37 anomalies, consisting of 22 magnetic targets (see Figures 5-1 to 5-6, Table 5-2) meet and/or exceed the 50-gamma/65-foot criteria, none meet Gearhart's 2011 magnetic orientation and spatial criteria to be considered potentially significant.

The Target No. can be a grouping of anomalies or a single anomaly. For example, Target No. T1 consists of five magnetic anomalies (1-9, 26, 3-7, 4-4, 5-4).

Four magnetic targets $(T 4, T 11, T 14$, and $T 18)$ are interpreted as relic oil wells. The interpretation is based on the review of the Railroad Commission of Texas (RCT) oil and gas well location maps in conjunction with magnetic contour maps. One unidentified target (T7) is interpreted as unidentified ferrous debris. Although T7 (1,348 gammas with a 170-foot duration) meets or exceeds the 50gamma/65-foot criteria, it does not meet the magnetic orientation requirement of the Gearhart 2011 model. The magnetic orientation of the positive and negative signatures of the target is $34^{\circ}$, exceeding the 26-degree deviation from magnetic north. Using the shipwreck discussed in Chapter 3, Site 41 CL92, located by this method as an example for magnetic contour orientation relative to magnetic north, T7 is not considered a potential shipwreck. 
Table 5-1. Recorded Magnetic Anomalies.

\begin{tabular}{|c|c|c|c|c|c|}
\hline Line & $\begin{array}{c}\text { Anomaly } \\
\text { No. }\end{array}$ & $\begin{array}{c}\text { Max. } \\
\text { deflection }\end{array}$ & $\begin{array}{l}\text { Duration } \\
\text { (fi) }\end{array}$ & Type & Comment \\
\hline 0 & OB48-3 & 114.2 & 42 & $M$ & ferrous debris \\
\hline 0 & OB 17-4 & 101.9 & 47 & $M$ & ferrous debris \\
\hline 0 & OB48-2 & 3366.32 & 98 & $C$ & pipeline \\
\hline 0 & OB48-1 & 2192.8 & 86 & $M$ & pipeline \\
\hline 0 & OB50-1 & 2625.2 & 103 & $M$ & pipeline \\
\hline 0 & OB17-3 & 1809.5 & 529 & $\mathrm{C}$ & pipeline \\
\hline 0 & OB23-1 & 1283.6 & 84 & $M$ & pipeline \\
\hline 0 & OB17-2 & 111.3 & 124 & $\mathrm{D}$ & ferrous debris \\
\hline 0 & OB 17-1 & 38.94 & 79 & M & ferrous debris \\
\hline 1 & $1-9$ & 1543 & 356 & $\mathrm{D}$ & directional well* \\
\hline 1 & $1-8$ & 5 & 34 & $M$ & ferrous debris \\
\hline 1 & $1-7$ & 8.5 & 50 & $\mathrm{D}$ & ferrous debris \\
\hline 1 & $1-6$ & 9.8 & 209 & $M$ & ferrous debris \\
\hline 1 & $1-4$ & 20.7 & 217 & $\mathrm{C}$ & ferrous debris; within the avoidance buffer of Mag-8 Gearhart (2016) \\
\hline 1 & $1-3$ & 291.9 & 24 & M & ferrous debris \\
\hline 1 & $1-1$ & 16.3 & 89 & $M$ & ferrous debris \\
\hline 1 & $1-2$ & 41.1 & 727 & $\mathrm{C}$ & oil well; dry* \\
\hline 1 & $1-11$ & $3,354.10$ & 2780 & $C$ & pipeline \\
\hline 1 & $1-10$ & 308 & 349 & M & ferrous debris \\
\hline 1 & $1-5$ & 238.1 & 125 & M & ferrous debris \\
\hline 2 & $2-6$ & 200 & 1127 & M & directional well* \\
\hline 2 & $2-5$ & 6.4 & 314 & $M$ & ferrous debris \\
\hline 2 & $2-4$ & 132.3 & 43 & $M$ & ferrous debris \\
\hline 2 & $2-1$ & 288.3 & 684 & $M$ & oil well; dry* \\
\hline 2 & $2-8$ & 3012.9 & 1005 & C & pipeline \\
\hline 2 & $2-3$ & 1236.35 & 615 & $M$ & pipeline \\
\hline 2 & $2-7$ & 21.2 & 459 & $\mathrm{D}$ & ferrous debris \\
\hline 2 & $2-2$ & 175.5 & 84 & $M$ & ferrous debris \\
\hline 3 & $3-7$ & 75.3 & 990 & $M$ & directional well* \\
\hline 3 & $3-5$ & 8.9 & 72 & C & ferrous debris \\
\hline 3 & $3-4$ & 39 & 205 & $M$ & ferrous debris \\
\hline 3 & $3-2$ & 16.2 & 53 & $C$ & ferrous debris \\
\hline 3 & $3-1$ & 6939.5 & 874 & $C$ & oil well; dry* \\
\hline 3 & $3-8$ & 5246.5 & 1918 & $C$ & pipeline \\
\hline 3 & $3-3$ & 1517.8 & 177 & $M$ & pipeline \\
\hline 3 & $3-6$ & 326 & 188 & $\mathrm{D}$ & ferrous debris \\
\hline 4 & $4-4$ & 23.1 & 1075 & $M$ & directional well* \\
\hline 4 & $4-1$ & 14918.2 & 688 & $\mathrm{D}$ & oil well; dry* \\
\hline 4 & $4-2$ & 91.6 & 51 & $C$ & oil well; dry* \\
\hline 4 & $4-6$ & 2707.1 & 728 & $C$ & Pipeline \\
\hline 4 & $4-5$ & 71.5 & 78 & C & ferrous debris \\
\hline 4 & $4-3$ & 74.8 & 114 & $M$ & ferrous debris \\
\hline 5 & $5-4$ & 13.2 & 784 & $M$ & directional well* \\
\hline 5 & $5-3$ & 35.25 & 243 & C & ferrous debris \\
\hline 5 & $5-1$ & 7508.1 & 616 & C & Pipeline \\
\hline 5 & $5-7$ & 700.5 & 479 & $\mathrm{D}$ & Pipeline \\
\hline 5 & $5-2$ & 23.2 & 156 & $\mathrm{D}$ & ferrous debris \\
\hline 5 & $5-9$ & 734.7 & 822 & $M$ & oil well; dry hole* \\
\hline 5 & $5-5$ & 57.7 & 211 & $\mathrm{D}$ & ferrous debris \\
\hline 5 & $5-6$ & 52.1 & 53 & $M$ & ferrous debris \\
\hline 5 & $5-8$ & 123.2 & 166 & $\mathrm{D}$ & ferrous debris \\
\hline 6 & $6-3$ & 25.3 & 164 & $\mathrm{D}$ & ferrous debris \\
\hline 6 & $6-5$ & 15.83 & 126 & $M$ & ferrous debris \\
\hline
\end{tabular}




\begin{tabular}{|c|c|c|c|c|c|}
\hline Line & $\begin{array}{c}\text { Anomaly } \\
\text { No. }\end{array}$ & $\begin{array}{c}\text { Max. } \\
\text { deflection }\end{array}$ & $\begin{array}{c}\text { Duration } \\
\text { (ft) }\end{array}$ & Type & Comment \\
\hline 6 & $6-10$ & 65.6 & 710 & C & oil well; dry* \\
\hline 6 & $6-1$ & 2468.37 & 943 & C & $\begin{array}{l}\text { Pipeline } \\
\end{array}$ \\
\hline 6 & $6-9$ & 1060.5 & 370 & C & Pipeline \\
\hline 6 & $6-2$ & 31.44 & 629 & M & ferrous debris \\
\hline 6 & $6-4$ & 1526 & 125 & $\mathrm{D}$ & ferrous debris \\
\hline 6 & $6-6$ & 13.9 & 283 & C & ferrous debris \\
\hline 6 & $6-8$ & 86.2 & 46 & $M$ & ferrous debris \\
\hline 6 & $6-7$ & 76.1 & 208 & $M$ & ferrous debris \\
\hline 7 & $7-2$ & 350.3 & 441 & C & ferrous debris \\
\hline 7 & $7-1$ & 4525.1 & 476 & C & Pipeline \\
\hline 7 & $7-3$ & 78.1 & 576 & C & Pipeline \\
\hline 7 & $7-4$ & 930 & 559 & C & Pipeline \\
\hline 7 & $7-5$ & 64.4 & 1072 & $\mathrm{C}$ & Pipeline \\
\hline 13 & $13-1$ & 48.1 & 386 & $C$ & ferrous debris \\
\hline 13 & $13-2$ & 887.62 & 615 & C & Pipeline \\
\hline 13 & $13-3$ & 120.3 & 117 & $C$ & Pipeline \\
\hline 14 & $14-3$ & 546 & 459 & C & Pipeline \\
\hline 14 & $14-2$ & 245 & 175 & C & ferrous debris \\
\hline 14 & $14-1$ & 64.7 & 347 & $C$ & ferrous debris \\
\hline 15 & $15-2$ & 11 & 147 & $\mathrm{D}$ & ferrous debris \\
\hline 15 & $15-3$ & 5.8 & 241 & $M$ & ferrous debris \\
\hline 15 & $15-5$ & 8.7 & 211 & $M$ & ferrous debris \\
\hline 15 & $15-6$ & 7.9 & 127 & $M$ & ferrous debris \\
\hline 15 & $15-8$ & 13 & 172 & $M$ & ferrous debris \\
\hline 15 & $15-7$ & 2953 & 398 & $\mathrm{D}$ & Pipeline \\
\hline 15 & $15-1$ & 51.7 & 208 & $M$ & ferrous debris \\
\hline 15 & $15-4$ & 223.5 & 170 & $\mathrm{D}$ & ferrous debris \\
\hline 16 & $16-2$ & 369.3 & 171 & $\mathrm{D}$ & ferrous debris \\
\hline 16 & $16-1$ & 75.5 & 103 & C & ferrous debris \\
\hline 16 & $16-4$ & 10.8 & 284 & $M$ & ferrous debris \\
\hline 16 & $16-5$ & 14 & 258 & M & ferrous debris \\
\hline 16 & $16-9$ & 5.6 & 108 & $\mathrm{D}$ & ferrous debris \\
\hline 16 & $16-6$ & 60.75 & 176 & $C$ & oil well; dry* \\
\hline 16 & $16-7$ & 171.9 & 778 & $C$ & Pipeline \\
\hline 16 & $16-3$ & 1348.9 & 368 & $M$ & ferrous debris \\
\hline 16 & $16-8$ & 198.5 & 228 & D & ferrous debris \\
\hline 17 & $17-1$ & 27.2 & 199 & $M$ & ferrous debris \\
\hline 17 & $17-3$ & 23.5 & 229 & $C$ & ferrous debris \\
\hline 17 & $17-4$ & 1077 & 1299 & C & pipeline \\
\hline 17 & $17-2$ & 15.7 & 152 & $M$ & ferrous debris \\
\hline 18 & $18-9$ & 14.7 & 123 & $M$ & ferrous debris \\
\hline 18 & $18-8$ & 13 & 698 & $M$ & ferrous debris \\
\hline 18 & $18-7$ & 13.2 & 27 & $M$ & ferrous debris \\
\hline 18 & $18-6$ & 9.2 & 214 & $M$ & ferrous debris \\
\hline 18 & $18-5$ & 44.3 & 109 & $\mathrm{C}$ & ferrous debris \\
\hline 18 & $18-4$ & 14.66 & 787 & $M$ & ferrous debris \\
\hline 18 & $18-2$ & 11.6 & 44 & C & ferrous debris \\
\hline 18 & $18-1$ & 25.33 & 345 & $M$ & ferrous debris \\
\hline 18 & $18-3$ & 908.2 & 314 & C & pipeline \\
\hline 19 & $19-7$ & 14.1 & 42 & $M$ & ferrous debris \\
\hline 19 & $19-6$ & 10.4 & 106 & $M$ & ferrous debris \\
\hline 19 & $19-3$ & 14.8 & 475 & $\mathrm{D}$ & ferrous debris \\
\hline 19 & $19-2$ & 6.72 & 424 & $M$ & ferrous debris \\
\hline 19 & $19-1$ & 37.4 & 233 & $M$ & ferrous debris \\
\hline 19 & $19-5$ & 56 & 1296 & $M$ & oil well; dry* \\
\hline
\end{tabular}




\begin{tabular}{|c|c|c|c|c|c|}
\hline Line & $\begin{array}{c}\text { Anomaly } \\
\text { No. }\end{array}$ & $\begin{array}{c}\text { Max. } \\
\text { deflection }\end{array}$ & $\begin{array}{l}\text { Duration } \\
\text { (ft) }\end{array}$ & Type & Comment \\
\hline 19 & $19-8$ & 92.6 & 854 & C & ferrous debris \\
\hline 19 & $19-4$ & 1268.2 & 628 & C & pipeline \\
\hline 22 & $22-1$ & 3010.6 & 88 & $M$ & pipeline \\
\hline 22 & $22-2$ & 292.4 & 28 & $D$ & ferrous debris \\
\hline 24 & $24-1$ & 121.3 & 76 & $\mathrm{D}$ & pipeline \\
\hline 25 & $25-1$ & 27.5 & 87 & $M$ & ferrous debris \\
\hline 26 & $26-1$ & 1753.36 & 227 & $\mathrm{D}$ & pipeline \\
\hline 27 & $27-1$ & 1072.5 & 158 & $\mathrm{D}$ & pipeline \\
\hline 28 & $28-1$ & 767.9 & 182 & $\mathrm{D}$ & pipeline \\
\hline 29 & $29-1$ & 1019.3 & 300 & $\mathrm{D}$ & pipeline \\
\hline 30 & $30-1$ & 698 & 220 & $\mathrm{D}$ & pipeline \\
\hline 31 & $31-1$ & 469.9 & 297 & C & pipeline \\
\hline 32 & $32-1$ & 1983.1 & 154 & $\mathrm{D}$ & pipeline \\
\hline 33 & 33-1 & 1657.7 & 119 & $M$ & pipeline \\
\hline 34 & $34-1$ & 2512.5 & 136 & $M$ & pipeline \\
\hline 35 & $35-1$ & 2435.5 & 206 & $D$ & pipeline \\
\hline 41 & $41-1$ & 2424.5 & 101 & $\mathrm{D}$ & pipeline \\
\hline 42 & 42-1 & 822.5 & 163 & $\mathrm{D}$ & pipeline \\
\hline 43 & 43-1 & 1448.5 & 197 & $\mathrm{D}$ & pipeline \\
\hline
\end{tabular}

Key: $M=$ monopole; $D=$ dipole; and $C=$ Complex.

*As per Railroad Commission of Texas terminology. 
REMOVED FROM PUBLIC COPY

Magnetic contour map of the project area.

Note the constant anomaly along the existing pipelines (Sheet 1 of 6 ). 
REMOVED FROM PUBLIC COPY

Magnetic contour map of the project area.

Note the constant anomaly along the existing pipelines (Sheet 2 of 6 ). 
REMOVED FROM PUBLIC COPY

Magnetic contour map of the project area.

Note the constant anomaly along the existing pipelines (Sheet 3 of 6 ). 
REMOVED FROM PUBLIC COPY

Magnetic contour map of the project area.

Note the constant anomaly along the existing pipelines (Sheet 4 of 6). 
REMOVED FROM PUBLIC COPY

Magnetic contour map of the project area.

Note the constant anomaly along the existing pipelines (Sheet 5 of 6 ). 
REMOVED FROM PUBLIC COPY

Magnetic contour map of the project area.

Note the constant anomaly along the existing pipelines (Sheet 6 of 6 ). 
Table 5-2. Magnetic Targets and Associated Anomalies that Meet the 50-Gamma/65-Foot Criteria.

\begin{tabular}{|c|c|c|}
\hline Target No. & Anomaly Nos. & Comment \\
\hline \multirow{2}{*}{$\mathrm{T} 1$} & $15-1$ & ferrous debris \\
\hline & $16-2$ & ferrous debris \\
\hline \multirow{2}{*}{ T2 } & $1-10$ & ferrous debris \\
\hline & $2-7$ & ferrous debris \\
\hline T3 & $4-5$ & ferrous debris \\
\hline \multirow{2}{*}{$\mathrm{T} 4$} & $14-2$ & ferrous debris \\
\hline & $15-3$ & ferrous debris \\
\hline \multirow{5}{*}{ T5 } & $1-9$ & directional well* \\
\hline & $2-6$ & directional well* \\
\hline & $3-7$ & directional well* \\
\hline & $4-4$ & directional well* \\
\hline & $5-4$ & directional well* \\
\hline T6 & $7-2$ & ferrous debris \\
\hline \multirow{3}{*}{$\mathrm{T7}$} & $15-4$ & ferrous debris \\
\hline & $16-3$ & ferrous debris \\
\hline & $17-2$ & ferrous debris \\
\hline T8 & $6-4$ & ferrous debris \\
\hline T9 & $3-6$ & ferrous debris \\
\hline \multirow[b]{2}{*}{$\mathrm{T} 10$} & $5-5$ & ferrous debris \\
\hline & $6-6$ & ferrous debris \\
\hline \multirow{2}{*}{ T11 } & $18-4$ & ferrous debris \\
\hline & $19-5$ & oil well; dry hole* \\
\hline T12 & $4-3$ & ferrous debris \\
\hline \multirow{2}{*}{ T13 } & $5-6$ & ferrous debris \\
\hline & $6-8$ & ferrous debris \\
\hline T14 & $16-6$ & oil well; dry hole* \\
\hline T15 & $5-8$ & ferrous debris \\
\hline T16 & $1-5$ & ferrous debris \\
\hline T17 & $2-2$ & ferrous debris \\
\hline \multirow{6}{*}{ T18 } & $1-2$ & oil well; dry hole* \\
\hline & $2-1$ & oil well; dry hole* \\
\hline & $3-1$ & oil well; dry hole* \\
\hline & $4-1$ & oil well; dry hole* \\
\hline & $5-9$ & oil well; dry hole* \\
\hline & $6-10$ & oil well; dry hole* \\
\hline T19 & $16-8$ & ferrous debris \\
\hline \multirow{3}{*}{ T20 } & OB17-2 & ferrous debris \\
\hline & $22-1$ & ferrous debris \\
\hline & $24-1$ & ferrous debris \\
\hline \multirow{2}{*}{ T21 } & $18-8$ & ferrous debris \\
\hline & $19-8$ & ferrous debris \\
\hline \multirow{2}{*}{ T22 } & $14-1$ & ferrous debris \\
\hline & $16-1$ & ferrous debris \\
\hline T23 & $1-4$ & Mag 8 (Gearthart 2016) \\
\hline
\end{tabular}


While T7 is interpreted as unidentified ferrous debris, it is also possible the source object is a misplotted oil well. T7 retains a very similar magnetic signature to that of $\mathrm{T} 18$, which aligns with a relic oil well on the RCT maps. The nearest plotted oil well is approximately 250 meters (817 feet) west-southwest immediately outside the APE. Review of the remote sensing data collected outside of the APE did not record any residual magnetic signatures at or in the vicinity of the plotted oil well location. Based on the similar attributes of the magnetic signatures associated with plotted oil wells (T18) identified during the current survey, it is possible that the source object associated with T7 is a misplotted oil well.

Magnetic Target Number 23 (T23), consisting of a single anomaly (1-4), is located 12.19 meters ( 40 feet) outside of the current APE. This anomaly was identified from data collected outside of the APE during the current survey. It is situated within the 50-meter (164-foot) avoidance buffers of previously identified anomalies Mag 8 and Mag 9 recorded by SAM in 2016 (Gearhart 2016; see Figure 5-4). Anomaly $1-4$ is a complex 20.7/217-foot magnetic signature located 34.8 meters $(114$ feet) west-northwest from the center point for Mag 8. While it does not meet the 50gamma/65-foot criteria, it is likely attributed with the source object for Mag 8. It is also situated along the western perimeter of Mag 9 where the avoidance buffers overlap. This anomaly and its 50-meter (164-foot) avoidance buffer is situated outside of the construction footprint, it will not be impacted by the proposed undertaking.

No magnetic signatures were recorded within the portions of the avoidance buffers for Mag 7 and Mag 9 within the APE (see Figure 5-4). The lack of any residual magnetic signatures of the anomaly within the APE indicate that no portion of the ferrous source objects for the three magnetic anomalies extend into the current survey area. The recommended management actions for Mag 7 and Mag 9 is no further work. These anomalies and their 50-menter (164foot) avoidance buffers are situated outside of the proposed construction footprint and will not be impacted by the proposed undertaking.

The remaining 17 targets (T1-T3, T5, T6, T8$\mathrm{T} 10, \mathrm{~T} 12, \mathrm{~T} 13, \mathrm{~T} 15-\mathrm{T} 17$, and $\mathrm{T} 19-\mathrm{T} 22)$ are interpreted as ferrous debris scatters associated with the oil and natural gas industries, recreational and commercial fishing activities, and miscellaneous debris scattered from previously tropical storms and hurricanes. No further archaeological investigations are recommended.

\subsubsection{Side-Scan Survey Results}

Side-scan sonar records do not reveal any potentially significant submerged cultural resources within the current survey area. Sidescan sonar data for the seabed in the Webster to Seadrift Pipeline project area in general were flat and unremarkable. Only two acoustic anomalies (SST-1 and SST-2) consisting of man-made objects were recorded. SST-1 is an unidentified feature with corresponding magnetic anomalies 1-2, 2-1, 3-1, 4-1, 5-9, 610 (T18). Review of the RCT oil and gas well location maps reveals an exploratory oil well (dry) at this location (see Figures 5-8 to 5-13). The lack of sonar contacts for the remaining magnetic targets as well as those magnetic targets interpreted as the remains of relic oil wells (T4, T11, and T14) as well as T7 is attributed to the source objects for these targets being located below the silty bottom sediments.

SST-2 is identified as relief from a pipeline trench that has subsided into the seabed perpendicular to the study area. Review of pipeline location maps reveal the West Ranch to Point Comfort pipeline at this location. During the course of the current survey, possible natural features resembling live bottom (i.e. oyster beds) were also observed. 
REMOVED FROM PUBLIC COPY

Side-scan sonar mosaic of the project area (Sheet 1 of 6). 
REMOVED FROM PUBLIC COPY

Side-scan sonar mosaic of the project area (Sheet 2 of 6). 
REMOVED FROM PUBLIC COPY

Side-scan sonar mosaic of the project area (Sheet 3 of 6). 
REMOVED FROM PUBLIC COPY

Side-scan sonar mosaic of the project area (Sheet 4 of 6). 
REMOVED FROM PUBLIC COPY

Side-scan sonar mosaic of the project area (Sheet 5 of 6). 
REMOVED FROM PUBLIC COPY

Side-scan sonar mosaic of the project area (Sheet 6 of 6). 


\subsection{CONCLUSIONS AND RECOMMENDATIONS}

Gray \& Pape conducted a Phase I marine archaeological survey for the proposed Webster to Seadrift Pipeline Project. All marine fieldwork and reporting activities were completed with reference to state law (Antiquities Code of Texas [Title 9, Chapter 191 of the Texas Natural Resources Code] and Texas State rules found in the Texas Administrative Code [Title 13, part 2, Chapters 26 and 28]) for cultural resources investigations. Work was completed under Texas Antiquities Permit Number 9004. The USACE has been identified as the Lead Federal Agency.

The purpose of this study was to assess the number, locations, cultural affiliations, components, spatial distribution, data potential, and other salient characteristics of potential submerged cultural resources within the proposed project area. The project area includes approximately 391 hectares $(967$ acres) of submerged land in Calhoun and Jackson counties, Texas. The investigation was comprised of a comprehensive magnetic and acoustic remote sensing survey and target analysis to determine the presence or absence of potentially significant remote sensing targets that might be affected by proposed project activity.

Review of the online Texas Archeological Sites Atlas database resulted in a listing of all recorded marine archaeological sites, shipwrecks, and NRHP properties within 1.6 kilometers (1 mile) of the project APE. The research revealed that there have been two previous cultural resource surveys (Pearson et al. 1993; Gearhart 2016), conducted between 1993 and 2016, located partially within the project APE (Figure 3-1). Research also revealed that the avoidance areas for previously recorded magnetic anomalies (Mag 7, Mag 8, and Mag 9) identified by Gearhart (2016) are partially located within the survey area. These three magnetic anomalies were recommended for avoidance as they represent potential cultural resources (Gearhart 2016). There were no corresponding acoustic targets for all three anomalies. The NRHP status for each is undetermined.

Previous investigations revealed that there are no previously recorded sites within the current APE and one site (41CL88) located within 1.6 kilometers (1 mile) of the study corridor. Review of AWOIS database revealed that there are no reported shipwrecks within the APE. Research of the RTC online database reveals four relic oil wells within the APE.

The grid for the remote sensing survey within the open waters of the bay consisted of a total of 19 preplanned parallel track lines (Lines 0-19) at 20-meters (65.6-foot) line spacing within the survey corridor (see Figure 4-1). The remaining portions of the project area in Lavaca River and Catfish Bayou were surveyed at 20-meter (65.6foot) line spacing (Lines 22-43) oriented perpendicular to the survey corridor. The marine field investigations consisted of a magnetometer and side-scan sonar investigation of the proposed project area in safely navigable waters. A total of 284.6 kilometers (176.9 linear survey miles) were transected utilizing the magnetometer and sidescan sonar.

The survey was conducted on July 29 and 30, 2019. The survey required approximately 60person hours to complete. Comprehensive analysis of the magnetic and acoustic data recorded for this project resulted in the identification of 127 discrete magnetic anomalies, with 80 meeting or exceeding the Pearson and Linden (2014) 50-gamma/65-foot criteria. A total of 43 of the 80 anomalies that meet or exceed the 50-gamma/65-foot criteria are associated with existing pipelines. While the remaining 37 anomalies, consisting of 22 magnetic targets (T1-T22), meet and/or exceed the 50-gamma/65-foot criteria, they do not meet Gearhart's magnetic orientation and 
spatial criteria to be considered potentially significant. They are interpreted as relic oils wells, ferrous debris scatters associated with the oil and natural gas industries, recreational and commercial fishing activities, and miscellaneous debris from previous tropical storms and hurricanes (see Table 5-2). Review of the sonar record revealed two distinct acoustic targets (SST-1 and SST-2) consisting of the remnants of a subsequent exploratory oil well and a subsided pipeline trench.

Based on the applied criteria, these magnetic and acoustic anomalies do not exhibit any characteristics associated historic shipwrecks and/or other significant submerged cultural resources. The recommended management action for the 22 magnetic targets, $\mathrm{T} 1-\mathrm{T} 22$, as well as the two acoustic anomalies, SST-1 and SST-2, is no further archaeological investigations.

One magnetic target, T23, situated outside of the APE, is associated with previously recorded anomaly Mag 8, which was deemed as potential historic shipwreck remains (Gearhart 2016). It is located outside of the APE; however, it was recorded within the 50-meter (164 foot) avoidance buffer of previously recorded anomaly Mag 8. While, no magnetic signatures were recorded within the portion of the avoidance buffer that is within the APE, neither Mag 8 or its avoidance buffer extend into the proposed workspaces; and therefore, will not be impacted by the proposed activities.

Additionally, no magnetic signatures associated with previously recorded anomalies Mag 7 and Mag 9 were identified in the 50-meter (164foot) avoidance buffers within the APE. While the lack of any residual magnetic signatures of anomalies (Mag 7 and Mag 9) within the 50meter (164-foot) buffer zones indicate that no portions of the ferrous source objects for these two magnetic anomalies extend into the APE, neither anomalies or their avoidance buffers extend into the proposed work spaces. The avoidance buffers for Mag 7 and Mag 9 will not be impacted by the proposed activities.

Gray \& Pape recommends no further archaeological investigations for magnetic targets, T1-T22 and acoustic targets, SST-1 and SST-2. Gray \& Pape also recommends avoidance of the 50-meter (164-foot) avoidance buffers for targets Mag 7, Mag 8, and Mag 9, discovered during the archeology investigation from Texas Antiquities Permit No. 7431 (Gearhart 2016), be avoided by all project activities. If the avoidance buffers cannot be avoided from bottom disturbing activities, Gray and Pape recommends diverground-truthing to identify and evaluate the magnetic source objects of Mag 7, Mag 8, and Mag 9. 


\subsection{REFERENCES CITED}

Armstrong, N.E.

1987 The Ecology of Open-Bay Bottoms of Texas: A Community Profile. U. S. Fish and Wildlife Service Biological Report 85 (7.12).

Aten, Lawrence E.

1984 "Woodland Cultures on the Texas Coast". In Perspective on Gulf Coast History, edited by Dave D. Davis, pp. 72-93. Ripley P. Bullen Monographs in Anthropology and History, No. 5. Florida State Museum, University Presses of Florida, Gainesville.

Borgens, Amy A.

2011 "Maritime Archaeology of the Northern Gulf of Mexico: Archaeology from the Age of Exploration to the Twilight of Sail". Chapter 29 in The Oxford Handbook of Maritime Archaeology, edited by Alexis Catsambis, Ben Ford, and Donny L. Hamilton, pp.660-684. Oxford University Press, New York, New York.

Borgens, Amy, Sara G. Laurence, and Robert L. Gearhart II

2012 Marine Geophysical Survey for Historic Properties, Matagorda Bay Ship Channel and Potential Placement Areas, Matagorda Ship Channel Improvement Project, Matagorda and Lavaca Bays, Texas. Report on file at Texas Historic Commission un Texas Antiquities Permit No. 4080.

Breiner, Sheldon

1973 Applications Manual for Portable Magnetometers. GeoMetrics, Sunnyvale, CA.

Bruseth, James E. and Toni S. Turner

2005 From a Watery Grave: The Discovery and Excavation of La Salle's Shipwreck, La Belle.

Texas A\&M University Press, College Station.

Campbell, T.N.

1958 Archaeological Remains from the Live Oak Point Site, Aransas County, Texas. The Texas Journal of Science 10:432-442.

Carrell, Toni

2017 "Hull Analysis". In James E. Bruseth, Amy Borgens, Bradford M. Jones, and Eric D. Ray eds. La Belle: The Archaeology of a Seventeenth-Century Ship of New World Colonization, pps. 83-130. Texas A\&M University Press, College Station, Texas.

Chappelle, Howard

1951 American Small Sailing Craft. W.W. Horton and Company, New York.

Comeaux, Malcolm, L.

1985 "Folk Boats of Louisiana". In Louisiana Folklife: A Guide to the State, edited by Nicholus Spitzer, pp. 160-178. Published by the Louisiana Folklife Program, $f$ the Arts and the Center for Gulf South History and Culture. 
Condron, Frank P.

2011 "Edna Theatre." National Register of Historic Places Registration Form. Austin, Texas, March 14, 2011.

Corbin, J.E.

1974 "A Model for Cultural Succession for the Coastal Bend Area of Texas". Bulletin of the Texas Archaeological Society 45:29-54.

Ferguson, John C.

1984 "Matagorda Island Lighthouse." National Register of Historic Places Inventory/Nomination Form. Austin, Texas, April 1984.

Folger, David W.

1972 "Characteristics of estuarine sediments of the United States". Geological Survey Professional Paper 742. United States Department of the Interior, Washington DC.

Freeman, Joe C., Martha Doty Freeman, and Linda C. Flory

1979 "Texana Presbyterian Church." National Register of Historic Places Inventory/Nomination Form. Austin, Texas, July 12, 1979.

Garrison, E.G., C.P. Giammona, F.J. Kelly, A.R. Tripp, and G.A. Wolff

1989 Historic shipwrecks and magnetic anomalies of the Northern Gulf of Mexico: Reevaluation of Archaeological Resource Management Zone 1. Vol. 2: Technical Narrative. OCS Study, MMS 89-00024. United States Department of the Interior, Minerals Management Service, Gulf of Mexico OCS Region.

Gearhart, Robert L., II

2011 "Archaeological Interpretations of Marine Magnetic Data". Chapter 4 in The Oxford Handbook of Maritime Archaeology, edited by Alexis Catsambis, Ben Ford, and Donny L. Hamilton, pp.90-1 13. Oxford University Press, New York, New York.

Gearhart, Robert

2016 Marine Archaeology Survey of Proposed West Ranch to Point Comfort Pipeline, Calhoun County, Texas. Prepared for Blanton and Associates. Survey and Mapping, LLC.

2017 Marine Archaeology Survey in Support of Lavaca Bay Reef Project Calhoun County, Texas. Prepared for The Texas Parks and Wildlife Department. Bob Hydrographics, LLC.

Hester, Thomas R.

1976 Hunters and Gatherers of the Rio Grande Plain and Lower Texas Coast of Texas. Center for Archaeological Research. The University of Texas at San Antonio.

Johnson, Donald S.

2002 La Salle: A Perilous Odyssey from Canada to the Gulf of Mexico. Cooper Square Press, New York. 
Jurgens, Christopher J

1989 Additional Archeological Survey of Proposed Wastewater System Construction at Riviera Water Control and Improvement District, Kleberg County, Texas. Construction Grants Division, Texas Water Development Board.

Linden, Sarah and C. E. Pearson

2014 Phase I Marine Cultural Resources Remote Sensing Survey in Buffalo Bayou for the Proposed Kinder Morgan Export Terminal, Pasadena, Harris County, Texas. Prepared for Environmental Management Resources Southwest, Inc., Houston, Texas by Coastal Environments, Inc., Corpus Christi, Texas.

Lipscomb, Carol A.,

2010 "Karankawa Indians" Handbook of Texas Online. Available URL: http://www.tshaonline.org/handbook/online/articles/bmk05 accessed December 11, 2019.

Malsch, Brownson

2017 "Indianolo, Texas" Handbook of Texas Online. Available URL:(http://www.tshaonline.org/handbook/online/articles/hep07) accessed July 2019

Maywald, Lonnie Ficklen

2010 "Port Lavaca, Texas". Handbook of Texas Online. Available URL:(http://www.tshaonline.org/handbook/online/articles/hep07) accessed July 2019.

Miller, Wesley

1997 Soil Survey of Jackson County, Texas. United States Department of Agriculture - Soil Conservation Service, Washington, DC.

Morison, Samuel Eliot

1974 The European Discovery of America: Volume 2: The Southern Voyages A.D.1492-1616. Oxford University Press.

Mowery, Irvin C., and James E. Bower

1978 Soil Survey of Calhoun County, Texas. United States Department of Agriculture - Soil Conservation Service, Washington, DC.

Newcomb Jr. W.W.

1961 The Indians of Texas. From Prehistoric Times to Modern Times. The University of Texas, Austin, Texas

National Oceanic and Atmospheric Administration (NOAA)

1958 Matagorda Bay and Approaches. https://historicalcharts.noaa.gov/historicals/preview/image/3N207-09L. Accessed June 13, 2019.

1995 Matagorda Bay. https://historicalcharts.noaa.gov/image $=11317-7-1995$. Accessed July 2019.

2014 Navigation Chart 11317 entitled, Matagorda Bay: Including Lavaca and Tres Palacios Bays. 33rd edition. 
2019 Port Lavaca, $\quad$ TX $\quad$ Station $\quad$ ID: 8773259.

https://tidesandcurrents.noaa.gov/stationhome.html?id=8773259. Accessed on July 30, 2019.

Parry, J. H.

1966 The Spanish Seaborne Empire. University of California Press, Berkeley, California.

Pearson, Charles E.

2010 Cultural Resources Remote-Sensing Survey of Halfmoon Reef, Matagorda Bay, Matagorda County, Texas. Coastal Environments, Inc., Baton Rouge.

Pearson, Charles E. and Allen R. Saltus

1993 Underwater Archaeology on the Ouachita River, Arkansas: The Search for the Chieftain,

Haydee, and Homer. Coastal Environments, Inc., Baton Rouge. Report submitted to the Vicksburg

District, U.S. Army Corps of Engineers, Vicksburg.

Pearson, C. E., Bryan L. Guevin and Allen R. Saltus, Jr.

1991 Remote-Sensing Survey of the lower pearl and West Pearl Rivers, Lovisiana and Mississippi.

Prepared for the United States Army Corps of Engineers, Galveston District. Coastal Environments, Inc., Baton Rouge Louisiana.

Pearson, C.E. and K.G Hudson

1990 Magnetometer Survey of the Matagorda Ship Channel: Matagorda Peninsula to Point Comfort, Calhoun and Matagorda Counties Texas. Prepared for the United States Army Corps of Engineers, Galveston District, by Coastal Environments, Inc., Baton Rouge Louisiana.

Pearson, Charles, Stephen R. James, Kay Hudson, and James Duff

1993 Underwater Archaeology Along the Lower Navidad and Lavaca Rivers, Jackson County, Texas. Coastal Environments, Inc. Baton Rouge.

Pearson, Charles E., George J. Castille, Donald Davis, Thomas E. Redard, and Allen R. Saltus 1989 A History of Waterborne Commerce and Transportation Within the U.S. Army Corps of Engineers New Orleans District and an Inventory of Known Underwater Cultural Resources. Submitted to the New Orleans District, U.S. Army Corps of Engineers, New Orleans.

Peebles, Robert H.

2015 "Shipbuilding", Handbook of Texas Online. Available URL: (https://tshaonline.org/handbook/online/articles/ets03) accessed July 2019. Porter, David D.

1998 The Naval History of the Civil War. Dover Publications, Inc., Mineola, New York.

Ricklis, Robert A., and Richard A. Weinstein

2005 "Sea-Level Rise and the Fluctuation along the Texas Coast: Exploring Cultural-Ecological Correlates" Gulf Coast Archaeology: The Southeastern United States and Mexico. Nancy M. White ed. University Press of Florida, Gainesville, Florida.

Roell, Craig $\mathrm{H}$.

2015 "Linnville, Texas", Handbook of Texas Online. Available URL: (https://tshaonline.org/handbook/online/articles/HVL58) accessed July 2019. 
Saltus, Allen

1987 Submerged Cultural Resources Investigation of the Western Portion of the Maurepas Basin. Submitted to the Division of Archaeology, Baton Rouge.

1988 Submerged Cultural Resources Investigation of Various Waterways of Lake Pontchartrain's North Shore. Archaeological Research and Survey. Submitted to the State of Louisiana, Department of Culture, Recreation and Tourism, Division of Archaeology, Baton Rouge.

Sharf, Thomas J.

1966 History of the Confederate States Navy. Random House Trade; Reprint edition (1996).

Texas General Land Office (TxGLO)

1994 "Navidad River Wreck Archeological Site No. 41 JK9." National Register of Historic Places Registration Form. Austin, Texas, August 19, 1994.

Texas Historical Commission

2019a "U and I", THC Shipwreck \# 1947. Atlas Number 8300001947. Texas Archeological Sites Atlas. Accessed July 2019.

2019b "Unknown", THC Shipwreck \# 1238. Atlas Number 8300001238 . Texas Archeological Sites Atlas. Accessed July 2019.

2019c "Unknown", THC Shipwreck \#1235. Texas Archeological Sites Atlas. Atlas Number 8300001235 . Accessed July 2019.

2019d Archeological Site Form 41CL88. Texas Archeological Sites Atlas. Atlas Number 9057008899. Accessed July 2019

2019e Historical Marker, "Site of the Town of Linnville". Texas Archeological Sites Atlas. Atlas Number 5057003091. Accessed July 2019.

$2019 f$ Archeological Site Form 41CL92. Texas Archeological Sites Atlas. Atlas Number 9057009299. Accessed July 2019.

Texas State Historical Association (TSHA)

2019 "Point Comfort, Texas". Handbook of Texas Online Available URL:

(http://www.tshaonline.org/handbook/online/articles/hip 10) accessed August 2019.

Townsend, Tom

1996 Texas Treasure Coast. Eakin Press, Austin, Texas.

Tuttle, Michael C.

2004 Duke Energy Hubline Marine Archaeological Services. Report produced by Panamerican Consultants, Inc., Memphis.

Tuttle, Michael C., Stephen R. James, Jr., Whitney J. Autin, and Amy M. Mitchell 2001 Cultural Resources Remote-Sensing Survey of the Navigation Channel Within Pools 3, 4, and 5 of the Red River Waterway, Lovisiana. Panamerican Consultants, Inc., Memphis, TN. Submitted to the USACE, Vicksburg District. 
Turner, E. S., and T. R. Hester

1993 A Field Guide to Stone Artifacts of Texas Indians, $2^{\text {nd }}$ Edition. Texas Monthly Field Guide Series. Gulf Publishing Co., Houston.

United States Geological Survey (USGS)

1995a Kamey, Texas, 15 Minute Series (topographic). USGS, Washington, DC.

1995b Point Comfort, 15 Minute Series (topographic). USGS, Washington, DC.

United States Coast and Geodetic Survey (USCGS)

1888 Pass Cavallo, Lavaca and San Antonio Bays, Texas. Office of Coast Survey Historical Map and Chart Collection https://historicalcharts.noaa.gov/historicals/preview/image/LC00208_09_1888. Accessed July 2019.

1884 Pass Cavallo, Lavaca and San Antonio Bays, Texas. Office of Coast Survey Historical Map and Chart Collection https://historicalcharts.noaa.gov/historicals/preview/image/LC00208_09_1884. Accessed July 2019.

United States Department of Agriculture 2019 Official Soil Series Descriptions and Series Classification. https://soilseries.sc.egov.usda.gov/OSD Docs/L/LAEWEST.html. Accessed July 2019.

Weddle, Robert S.

2011 Handbook of Texas Online. "La Salle Expedition" http://www.tshaonline.org/handbook/online/articles/RR/pfr1.html. Accessed August 2019.

Wilson, Bonnie Tipton

2017 "Jackson County Monument." National Register of Historic Places Registration Form. Austin, Texas, October 2, 2017. 


\section{APPENDIX: PROJECT PLANS}

\section{REMOVED FROM PUBLIC COPY}

